\title{
US inflation and consumption: A long-term perspective with a level shift
}

\author{
Antonio Paradiso ${ }^{\mathrm{a}, *}$, Paolo Casadio ${ }^{\mathrm{b}}$, B. Bhaskara Rao $^{\mathrm{c}}$ \\ a National Institute for Statistics (ISTAT), Rome, Italy \\ b Intesa Sanpaolo Bank, Risk Management, Viale dell'Arte 18, 00144, Rome, Italy \\ c School of Economics and Finance, University of Western Sydney, Sydney, Australia
}

\section{A R T I C L E I N F O}

\section{Article history:}

Accepted 29 May 2012

\section{JEL classification:}

E21

C22

C32

E31

\section{Keywords:}

US consumption

Inflation

Interest rate

MEW

Level shift

Cointegration

\begin{abstract}
A B S T R A C T
This article examines the existence and stability of the consumption function in the United States of America (US) beginning in the 1950s. In order to obtain a stable long run relationship, we have introduced two innovative elements into the analysis of the life-cycle of the consumption function with wealth effects: 1) a shift level break in the cointegrating relationship, and 2) using inflation as an additional explanatory variable. By implementing a well structured estimation strategy, we found that after taking the level shift into account, a cointegrating equation, including inflation, exists and is more stable for the critical sub-samples than traditional consumption function models.
\end{abstract}

(c) 2012 Elsevier B.V. All rights reserved.

\section{Introduction}

The aim of this paper is to study personal consumption expenditure (PCE) in the US over a period spanning more than 50 years. Traditionally, consumption dynamics have been studied employing life-cycle models (LCM) of household behavior, in which wealth and income determine consumer spending. While earlier estimates of LCM have used classical methods of estimation, more recent estimates are based on time series methods of unit roots, cointegration and error correction specifications (see for example Ludvigson and Steindel, 1999; Davis and Palumbo, 2001 and more recently Donihue and Avramenko, 2006). The problem with the cointegration method is that it implicitly requires the existence of a stable long term relationship between consumption, income and wealth. However, in our sample of 50 years, there have been major changes in the structure of the economy due to changes in tax structure, demographics, productivity growth, financial structure, social insurance, and many other aspects of the economy (Carroll et al., 2006). Therefore, as Carroll et al. (2006) noted, trying to find the existence of a cointegrating relationship which satisfies the condition of stability is problematic. They criticized the idea long-run relationship and

\footnotetext{
* Corresponding author.

E-mail addresses: anto_paradiso@hotmail.com (A. Paradiso), raob123@bigpond.com (B.B. Rao).
}

estimated the marginal propensity to consume (MPC) out of wealth with alternative methods. ${ }^{1}$

In this paper we shall reexamine whether a stable long run consumption relationship exists with alternative specifications of the US consumption function that have been used in some influential empirical works. We introduce two innovative elements viz., allow for a level shift in the long term relationship during the last 10 years due to various shocks to the economy and introduce consumer price index (CPI) inflation as an additional explanatory variable. The hypothesis regarding a shift in the intercept introduces minimal changes in the statistical relationship, leaving the slope coefficients unchanged. However, CPI inflation seems to exert significant changes on consumption in several ways. The simplest is that inflation adversely affects consumer confidence and thus leads to increased saving. Inflation may also change the distribution of income among households and affect consumer behavior. However, most importantly, inflation can be linked to the cash-out mechanism, which seems to be operating from the beginning of the 1990s.

In our empirical work, we selected the best model following a structured decision-making process based upon rigid statistical properties. If a model successfully completed all the steps, then we could

\footnotetext{
${ }^{1}$ In particular, they estimated a dynamic equation of consumption derived from a sluggish adjustment hypothesis and found a higher housing wealth effect with respect to stock market wealth effect.
} 
Table 1

Summary and comparisons of selected empirical studies.

\begin{tabular}{|c|c|c|c|c|c|c|c|c|c|c|}
\hline Study & Period & Parameter & Technique & TW & FW & NFW & int. & infl. & $\mathrm{y}$ & MEW \\
\hline Taylor $(1971)^{a}$ & 1953Q1-1969Q4 & Elasticity & OLS & & & & $0.78 / 0.88$ & & & \\
\hline Heien (1972) & 1948-1965 & Elasticity & NONL & & & & -0.16 & & & \\
\hline Weber (1975) & 1930-1970 & Elasticity & NONL/ML & & & & POS & & & \\
\hline Mishkin (1976) & 1954Q1-1972Q4 & Elasticity & OLS/INST & & & & -0.2 & & & \\
\hline Springer $(1975,1977)$ & 1955Q1-1971Q4 & Elasticity & OLS & & & & POS/NEG & NEG/POS & & \\
\hline Howard (1978) & 1965Q1-1976Q4 & Elasticity & OLS & & & & NEG & & & \\
\hline Gylfason (1981) & 1952Q3-1978Q3 & Elasticity & OLS & & & & -0.03 & 0.03 & & \\
\hline Wilcox (1990) & 1955Q2-1989Q2 & Elasticity & OLS & & & & -0.03 & & & \\
\hline MacDonald et al. (2011)\# & 1991Q1-2006Q2 & Elasticity & ML & & & & -0.03 & NEG & & \\
\hline Ludvigson and Steindel (1999) & 1953Q1-1997Q1 & L. R. MPC & DOLS & 0.05 & & & & & 0.7 & \\
\hline Mehra (2001) & 1960Q2-2000Q2 & L. R. MPC & DOLS & $0.03 / 0.04$ & & & & & $0.57 / 0.62$ & \\
\hline Davis and Palumbo (2001) ${ }^{*}$ & 1960Q1-2000Q1 & L. R. MPC & DOLS & $0.04 / 0.06$ & 0.06 & 0.08 & & & & \\
\hline Benjamin et al. (2004)* & 1952Q4-2001Q4 & MPC & OLS & & 0.02 & $0.08 / 0.16$ & & & & \\
\hline Apergis and Miller (2004) & 1957Q1-2002Q1 & L. R. Elast. & ML & 0.04 & & & & & 0.60 & \\
\hline Carroll et al. (2006) ${ }^{* *}$ & 1960Q1-2004Q3 & L. R. MPC & INST & $0.07 / 0.06$ & $0.06 / 0.04$ & $0.15 / 0.09$ & & & & \\
\hline Donihue and Avramenko (2006) & 1953Q2-2005Q2 & L. R. MPC & DOLS/ML & 0.04 & 0.05 & 0.07 & & & $1.09 / 0.89$ & \\
\hline Fuentes and Hatzius $(2006)^{*}$ & 1968Q3-2005Q3 & L. R. MPC & GETS & 0.03 & & & & & & 0.62 \\
\hline Leonard $(2010)^{*}$ & 1952Q1-2005Q4 & MPC & OLS & & 0.02 & 0.10 & & & & \\
\hline
\end{tabular}

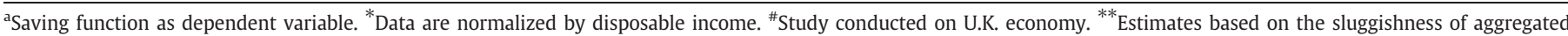

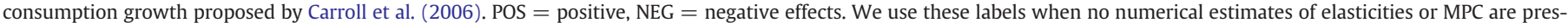

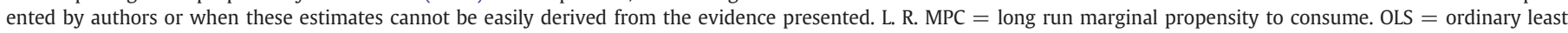

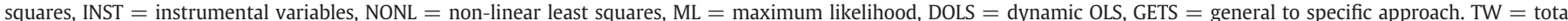

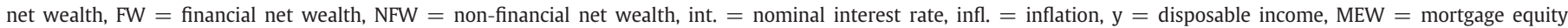
withdrawal.

say that the model satisfies the conditions for an existence and stability of a cointegrating relationship. Our empirical analysis suggests that the model using consumption, labor income, net wealth (split into stock market and non-stock market), the level shift in 2004, and CPI inflation is preferable to the others. Our analysis concludes with an examination of the asymmetrical effects of nominal interest rates on consumption.

This paper is organized as follows. Section 2 reviews previous empirical works. Section 3 illustrates the effect of inflation on consumption expenditure and the MEW mechanism. Section 4 shows the methodology used, Section 5 presents the results, and Section 6 concludes.

\section{Literature review}

Consumption models based on Friedman's (1957) permanent income hypothesis (PIH) and Ando and Modigliani's (1963) life-cycle hypothesis ( $\mathrm{LCH}$ ) have replaced the ad hoc specifications of the consumption functions based on the absolute income hypothesis (AIH) of Keynes and the early Keynesians. In both the PIH and LCH consumptions decisions are based on household's estimates of the long run income in contrast to current income in the $\mathrm{AIH}$. The relative merits of the PIH and LCH are well known and adequately discussed in the textbooks. Both theories adequately explain observed facts of which perhaps the most important is the equality between the average and marginal propensities to consume. However, the PIH and LCH differ in their measurement of long run income but they are treated as based on similar microeconomic household inter-temporal utility maximization models. The specification of the consumption function based on the LCH has been used in several recent empirical studies because it is more convenient for estimating the effects of some important variables that affect household wealth. For example, in the last 10 years, stimulated by sharp changes in equity markets and by the development of cointegration analysis, a growing number of empirical studies have focused on the link between stock market wealth and consumption.

Ludvigson and Steindel (1999), in an influential paper, employed a traditional LCM that links consumption, labor income and asset wealth, focusing on the wealth effects due to the stock market boom of the late 1990s. They found that a significant cointegrating relationship between consumption, income and wealth exists but it is not stable. Many other papers that followed Ludvigson and Steindel have also found a statistically significant cointegrating relationship between consumption, labor income and wealth; see for example Mehra (2001), Davis and Palumbo (2001), and Benjamin et al. (2004). A summary of these empirical studies can be found in Table 1 . However, Rudd and Whelan $(2002,2006)$ raised some doubts on the findings of these works. They argued that the measures of real consumption, income and wealth used in these studies were inconsistent with the budget constraints used in the optimization model. Rudd and Whelan (2002) show that if consumption, income and wealth are correctly measured, there is no cointegrating relationship. Their arguments are not new because ideally measured, consumption expenditure should include expenditure on non-durables plus the flow of services from durables. It is also well known that it is difficult to accurately estimate the value of the flow of services because different durables have different depreciation rates and changes in technology may greatly increase the depreciation rates, for example, electronic goods. For this reason, durables are usually omitted from aggregate consumption measure. While there is no consolidated theoretical framework that considers the consumption of durable goods to date, we guess that it is very important to consider the dynamics of this component of consumption in the analysis of the wealth effect. The consumption of durable goods is a component of private consumption, which we think will show a link to the business cycle pattern and asset markets dynamics. ${ }^{2}$ A recent study by Donihue and Avramenko (2006) looked for a cointegrating relationship between consumption (including durable goods), labor income and different forms of wealth over a wide sample period (from 1952 to 2006). ${ }^{3}$ This study showed that there is no cointegration if the criteria for significance are not extended to over $10 \%$ of the critical values. Carroll et al. (2006) were skeptical about the possibility of finding a stable cointegration relationship. They point out that changes in demographic factors and financial system may have caused a break in the consumption function.

\footnotetext{
2 We are thankful to Steven Fazzari who suggested this point during a conversation at a seminar.

${ }^{3}$ Unfortunately these authors do not eliminate durable goods from the measure of wealth as suggested by Rudd and Whelan $(2002,2006)$.
} 
Other studies have tried to identify additional explanatory variables in addition to the commonly used income and wealth in the LCM based consumption function. In the 1970s and 1980s nominal interest rates and inflation were added as additional variables to the US consumption and saving functions. Taylor (1971), Heien (1972), Mishkin (1976), Gylfason (1981) and Wilcox (1990) used nominal interest rates and found an inverse relationship between consumption and interest rates. Contradictory results have been presented by Weber (1975) and Springer (1975). Springer (1977) found that the effects of nominal interest rates and inflation are different for different components of aggregate consumption. Howard (1978) has reported evidence of a positive relationship between inflation and saving in the US, but found no evidence for the effects of interest rates. That these studies have focused on the effects of inflation is not coincidental because during much of the 1970s the inflation rate was high due to energy shocks. When inflation returned to normal levels, attention paid to the impact of inflation on consumption also declined.

More recent studies considered the role of mortgage equity withdrawal (MEW) in explaining consumption expenditure together with the variables traditionally included in the LCM viz., net wealth and labor income. Fuentes and Hatzius (2006) focused on the effect of MEW on consumption and found a statistically significant positive coefficient for MEW. Prakken (2006) analyzed Fuentes and Hatzius' (2006) results and demonstrated that their estimated equations suffer from some econometric problems. Firstly, they did not examine the long run relationship and secondly, the residual ADF test for cointegration is found to be non-stationary.

Another area of interest is the study of asymmetric effects of consumer wealth on consumption, particularly during the periods of bubbles in the stock market and the recent collapse of the housing market. Apergis and Miller (2004) found that positive shocks to the stock market have larger wealth affects on consumption than negative shocks. MacDonald et al. (2011) examined asymmetries in the consumption wealth relationship due to monetary policy changes in the UK. They found that changes in the interest rates inversely affect asset values but their wealth effects on consumption are asymmetric. Wealth reductions due to monetary tightening have a weaker impact on consumption spending than an increase in wealth due to an expansionary monetary policy.

\section{Consumption and inflation}

The effects of income and wealth on consumption are well known from a theoretical perspective. A less frequently debated aspect is the effect of inflation on consumer expenditure. Deaton (1977) started from the notion that economic agents have insufficient information to distinguish between relative and general price movements when both are changing simultaneously. Under these circumstances, unanticipated inflation is misinterpreted as the rise in relative prices of goods economic agents are currently buying, so that real saving increases. Other attempts to explain the phenomenon of rising saving rates when inflation is high are based on Katona (1975). Katona maintained that inflation causes uncertainty and pessimism about the future, pushing consumers to save more. Another direct effect of inflation is due to the incentive of holding real assets rather than assets fixed in nominal values, including consumer durable purchases (this effect is sometimes defined in literature as "flight from currency" (Howard, 1978)). In addition to the direct effects of inflation on consumption, there are also several indirect effects. For example, the erosion of the real value of nominal assets reduces the real value of wealth held in those assets; in this case the inflationary effect is connected with the role that liquid assets may play in consumption behavior (Forsyth (1975); Hendry and von Ungern-Stenberg (1981)). Inflation may also change the distribution of income among households (creditor and debtor, employee and employer etc.).
Furthermore, if different groups within the household show different propensities to consume and are subject to different taxes, redistribution will have an effect on aggregate savings (Howard, 1978).

Another important indirect effect of inflation on consumption passes through the cash-out mechanism, which seems to have operated from the beginning of the 1990s. This effect operates via the influence of inflation on nominal interest rate. ${ }^{4}$ The known empirical fact that high inflation is associated with high nominal interest rate (see footnote number 4 and Mishkin, 1992) allows us to concentrate on the role of interest rates in the cash-out mechanism. The cash-out mechanism is the effect coming from saved interest payment by debtors due to a fall in interest rate. There are two main cash-out effects. The first one is the mortgage equity withdrawal (MEW) - defined by the Federal Reserve (Greenspan and Kennedy, 2008) as "the discretionary initiatives of homeowners to convert equity in their homes into cash by borrowing in the home mortgage market" - because some households reduce equity in houses when the long term interest rates decline. The second effect is a more general one because a reduction in interest payments frees more resources for consumption. As the second cash-out effect is very intuitive, we will focus on the MEW effect.

Very few papers in the literature describe the MEW mechanism. Duca and Kumar (2011) maintain that the propensity for withdrawing housing equity rises with house price appreciation and with lower interest rates. In other words, home equity can be extracted if either of the following two events occurs: 1) the value of the house increases, or 2) the current mortgage rate goes below the historically contracted one. In such cases the mortgage can be renegotiated, by increasing the loan amount or decreasing the service of debt, and thus freeing resources. The meaningful variable regarding mortgage cash-out is the nominal mortgage rate because mortgage debt is contracted in nominal terms. Following the work of Duca and Kumar (2011), we identify house prices and mortgage interest rates as the key variables driving the equity extraction. Active $\mathrm{MEW}^{5}$ (AMEW) can thus be explained by means of a relationship involving the annual change in real house prices and the nominal fixed long term mortgage rate. The dynamic OLS (DOLS) estimate of this relationship is presented in Table 2.

Our view of the MEW mechanism has been empirically confirmed by the results in Table 2 . Since the dynamic of house prices has already been captured by the wealth component, the only component of the MEW mechanism not captured in the consumption estimation is the nominal long term interest rate. From the link between inflation and the nominal interest rates, we can conclude that inflation within the consumption function can carry information about cashout.

Even if inflation and nominal interest rates are positively correlated, there will be an additional informational component not properly captured by inflation. Changes in interest rates can explain consumption in

\footnotetext{
${ }^{4}$ According to the Fisher equation, the nominal interest rate is equal to the real return plus the expected inflation rate. If real returns are independent of inflation, then nominal interest rates should be positively related to expected inflation. In terms of long-run correlations, it suggests that nominal interest rates should be positively correlated with the average rates of inflation. See Walsh (2003) for more details. Mishkin (1992) examined the long-run correlation between interest rate and inflation for the U.S. applying the Engle-Granger methodology. He found the evidence that the two series are cointegrated and a long-run unitary response of nominal interest rates to movements in the inflation rate.

${ }^{5}$ The literature distinguishes between active and passive MEW. Active MEW consists of cash-out refinancing and home equity borrowing; meanwhile, passive MEW is the equity released automatically during the housing turnover process. Studies conducted on the link between MEW and consumption showed that housing gains obtained through the housing turnover process are not very important in terms of spending. For this reason, in our analysis, we refer to active MEW measures. In our estimation we consider a measure of real active MEW. The official measure of this series was calculated by Greenspan and Kennedy (2005). In 2005, they published a dataset on MEW which started in 1990. Kennedy regularly updates the data. The most recent reconstruction stopped in $2008 \mathrm{Q} 2$.
} 
Table 2

DOLS estimates of active MEW.

Model AMEW ${ }_{t}=\beta_{0}+\beta_{1} i_{t}^{m t g}+\beta_{2} \Delta_{4} p_{t}^{h}+\sum_{j=-k}^{k} \beta_{1, j} \Delta i_{t+j}^{m t g}+\sum_{j=-k}^{k} \beta_{2, j} \Delta\left(\Delta_{4} p_{t+j}^{h}\right)+\varepsilon_{t}$.

Long term relation $\mathrm{AMEW}_{t}=\beta_{0}+\beta_{1} i_{t}^{m t g}+\beta_{2} \Delta_{4} p_{t}^{h}+u_{t}$.

\begin{tabular}{llll}
\hline Sample period & $\beta_{0}$ & $\beta_{1}$ & $\beta_{2}$ \\
\hline 1991Q1-2008Q2 & 0.696 & $-0.389^{* * *}$ & $0.209^{* * *}$ \\
Residual ADF t-test & & $-4.09^{* *}$ & \\
\hline
\end{tabular}

Notes: ${ }^{*},{ }^{* *}$ and ${ }^{* * *}$ represent, respectively, significance levels of $10 \%, 5 \%$ and $1 \%$ AMEW indicates the natural logarithm of active MEW. Leads and lags of DOLS estimations were selected according to HQ criteria. The sample period denotes the range of data before data points for leads and lags are removed. For the residual ADF t-test the lag length was chosen by HQ criteria. Newey-West corrected t-statistics were applied in regression.

the short term. We will investigate whether a short term component can provide useful information in terms of consumption expenditure. Given the nature of the cash-out effect, we will question whether consumption responds asymmetrically to changes in interest rates. We expect to find strong evidence that a reduction in interest rates increases consumption.

\section{Methodology}

The main aim of this empirical analysis is to compare various specifications of two key consumption function formulations in order to find a stable cointegrating relationship: the traditional LCM and a version "augmented" for inflation. Following the most recent empirical literature on this topic, we consider the total net wealth as well as the various components of net wealth viz., stock and non-stock market wealth, housing and non-housing wealth, and liquid and illiquid wealth. We also analyze the same disaggregation in an alternative way where the first component is wealth in stocks, housing and liquid assets and the rest of the wealth is measured as residual wealth, which is calculated as the difference between the total net wealth and the asset under consideration. Details of the data construction and sources are in Appendix A.

The logic is simple: if a specification does not provide the required proof, then it is excluded from the successive steps and we can conclude that the variables in the equation are not cointegrated. A graphical illustration of the procedure used is reported in Fig. A1 in Appendix A. ${ }^{6}$

The starting point was the DOLS estimation technique of Stock and Watson (1993). After having verified that a model has statistically significant coefficients with the expected signs (STEP 1), we go through the following steps. An ADF residual test (STEP 2) was conducted on the residuals of a long run relationship estimated with DOLS. If the residuals are stationary, then additional (multivariate) tests (the Johansen trace test and the Saikkonen and Lutkepohl test (STEP 3)) are conducted in order to confirm the presence of a cointegrating relationship. However, if, as we expected following the conclusions of Section 1, the residuals appear to be nonstationary, additional analysis is required. We check, from a visual inspection of the residuals' t-statistics, ${ }^{7}$ whether a structural break had occurred. If this was the case, we move to STEP 2.1 in order to confirm the presence of a cointegrating relationship with a level shift through the Johansen trace test and the Saikkonen and Lutkepohl multivariate tests. The results of this step are reported in Table A1 in Appendix A.

\footnotetext{
${ }^{6}$ The use of flow-chart is only for easing the exposition of the logic followed. A flowchart is also used by Enders (1995) for explaining the logic procedure in testing for unit-root tests. A similar graph is also used by Asteriou and Hall (2007).

7 The break date can be identified by when the residuals were well below the critical points for the whole period, starting from 1990 (the start date of the residual tests), until an upward trend pushed the residual t-statistics above the critical values.
}

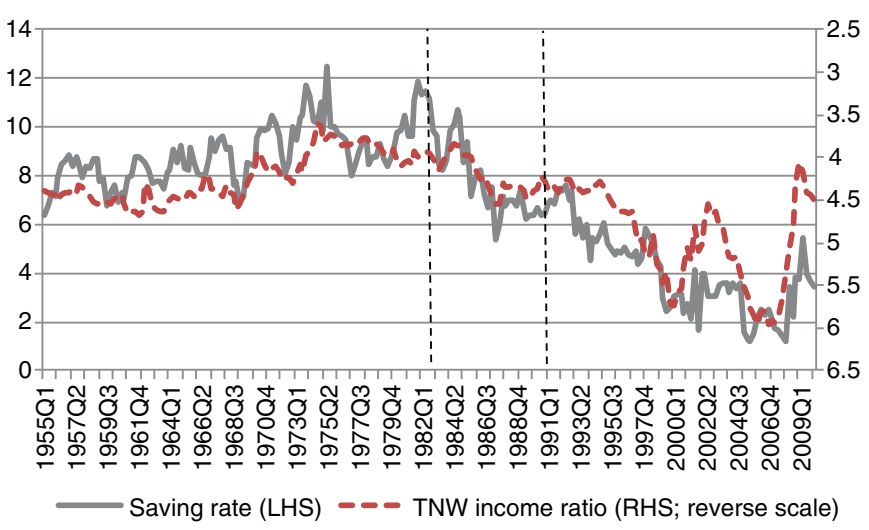

Fig. 1. Wealth-to-disposable-income ratio and personal saving rate. Source: U.S. Department of Commerce, Bureau of Economic Analysis; Board of Governors of the Federal Reserve System.

The break in the intercept causes minimal change to the statistical relationship. The subsequent step, STEP 4, aims to specify the cointegrating relationship by studying the signs and the statistical significance of the parameters entering into the long term relationship. We adopted four methods of estimation: DOLS, fully modified OLS (FMLS), canonical cointegrating regression (CCR) and the Johansen-maximum likelihood estimation (MLE). A restricted version of the VAR was employed alongside the Johansen-MLE procedure (a model that excludes from the ECM the factor loading of the other explanatory variables). The last step (STEP 5 ) entailed studying the stability of the "surviving" models following all the previous steps. A visual description of this is depicted in Fig. 1, which plots the savings ratio against the ratio of household net worth to disposable income.

From a visual inspection of Fig. 1 we selected the events which influenced the pattern of this relationship. Until the 1980s, the personal savings rate increased while the wealth-to-disposable-income-ratio plunged. These trends inverted after the beginning of the 1980s, when there was a change in the slope of both the savings rate and total net wealth ratio. Since the beginning of the 1990s, the wealth-saving relationship has "relaxed": the saving rate declined very steeply whereas the wealth ratio showed a less conclusive pattern. A view put forward by some authors (e.g. Duca, 2006; MacDonald et al., 2011) and other practitioners (Fuentes and Hatzius, 2006) is that the rapid increase in the conversion of homeowners equity to cash through borrowing in the home mortgage market (i.e., the MEW mechanism) caused the rapid decline in the savings rate during the 1990s. ${ }^{8}$ The last 10 years appears to be the most problematic in terms of this relationship: the savings rate is characterized by its strong volatility and the net wealth ratio features accentuated peaks and troughs. This dynamic is due to numerous events that affected the US economy during this period (e.g. the rise and fall in the stock market, the housing market bubble and the financial crisis).

Bearing in mind that stability is a difficult condition to satisfy in estimating a consumption function for a long period from the 1950s to the present day, we divided the sample period into three subsamples: 1955Q1-1980Q1, 1980Q1-2010Q1 and 1991Q1-2010Q1. This choice, as mentioned above, is not arbitrary: during the early years of the 1980s, the slopes of the savings rate and total-wealth-to-income ratio have changed since the inflation rate started falling, after the second oil shock. The early years of the 1990s were when nominal interest

\footnotetext{
8 The mechanism is the same mechanism explained in Section 3: the sharp increase in house prices and low interest rates favored the usage of MEW as an ATM machine for funding consumption spending (and in this way reducing personal saving); see Fuentes and Hatzius (2006), for example.
} 
Table 3A

Estimation results.

All sample comparisons.

\begin{tabular}{|c|c|c|c|c|c|c|c|c|}
\hline & \multirow{3}{*}{$\frac{\text { STEP } 1}{\overline{\text { DOLS estimation }}} \overline{\text { 1955q1-2010q1 }}$} & \multirow{3}{*}{$\begin{array}{l}\text { STEP } 2 \\
\text { Cointegration } \\
\text { dynamic test }\end{array}$} & \multirow{3}{*}{$\begin{array}{l}\text { STEP } 2.1 \\
\text { Cointegration }+ \\
\text { shift dummy }\end{array}$} & \multicolumn{5}{|c|}{ STEP 4 (sample 1955q1-2010q1) } \\
\hline & & & & \multicolumn{5}{|c|}{ Cointegration of different methods } \\
\hline & & & & DOLS & CCR & FMOLS & VAR-MLE & VAR-MLE Restr. \\
\hline \multicolumn{9}{|l|}{ Eq. (1) } \\
\hline Income & $0.753^{* * *}$ & NO & YES & $0.697^{* * *}$ & $0.67^{* * *}$ & $0.662^{* * *}$ & $0.533^{* * *}$ & $0.6^{* * *}$ \\
\hline TW & $0.284^{* * *}$ & (Fig. 2) & (Table A1) & $0.355^{* * *}$ & $0.379^{* * *}$ & $0.388^{* * *}$ & $0.499^{* * * *}$ & $0.451^{* * *}$ \\
\hline Shift(97q4) & - & & & $-0.036^{* * *}$ & $-0.04^{* *}$ & $-0.041^{* * *}$ & $-0.064^{* * *}$ & $-0.058^{* * *}$ \\
\hline Factor load. & - & & & - & - & - & $-0.039^{* * *}$ & -0.007 \\
\hline \multicolumn{9}{|l|}{ Eq. (2) } \\
\hline Income & $0.925^{* * *}$ & NO & No & & & & & \\
\hline TW & $0.141^{* * *}$ & (Fig. 2) & (Table A1) & & & & & \\
\hline Inflation & $-0.007^{* * *}$ & & & & & & & \\
\hline \multicolumn{9}{|l|}{ Eq. (3) } \\
\hline Income & $0.692^{* * *}$ & NO & YES & $0.621^{* * *}$ & $0.663^{* * *}$ & $0.656^{* * *}$ & $0.535^{* * *}$ & $0.481^{* * *}$ \\
\hline SW & $0.047^{* * *}$ & (Fig. 2) & (Table A1) & $0.055^{* * *}$ & $0.057^{* * *}$ & $0.057^{* * *}$ & $0.077^{* * *}$ & $0.06^{* * *}$ \\
\hline NSW & $0.298^{* * *}$ & & & $0.368^{* * *}$ & $0.332^{* * *}$ & $0.337^{* * *}$ & $0.415^{\text {*** }}$ & $0.489^{* * *}$ \\
\hline Shift(04q1) & - & & & $-0.042^{* * *}$ & $-0.037^{* * *}$ & $-0.038^{* * *}$ & $-0.045^{* * *}$ & $-0.039^{* * *}$ \\
\hline Factor load. & - & & & - & - & - & $-0.053^{* * *}$ & $-0.029^{\dagger}$ \\
\hline \multicolumn{9}{|l|}{ Eq. (4) } \\
\hline Income & $0.841^{* * *}$ & NO & YES & $0.771^{* * *}$ & $0.724^{* * *}$ & $0.717^{* * *}$ & $0.871^{* * *}$ & $0.785^{* * *}$ \\
\hline SW & $0.018^{* *}$ & (Fig. 2) & (Table A1) & $0.028^{* * *}$ & $0.034^{* * *}$ & $0.034^{* * *}$ & $0.029^{* * *}$ & $0.028^{* * *}$ \\
\hline NSW & $0.205^{* * *}$ & & & $0.268^{* * *}$ & $0.307^{* * *}$ & $0.313^{* * *}$ & $0.177^{\text {*** }}$ & $0.255^{* * *}$ \\
\hline Inflation & $-0.006^{* * *}$ & & & $-0.005^{* * *}$ & $-0.004^{* * *}$ & $-0.004^{* * *}$ & $-0.008^{* * *}$ & $-0.007^{* * *}$ \\
\hline Shift(04q1) & - & & & $-0.033^{* * *}$ & $-0.035^{* * *}$ & $-0.035^{* * *}$ & $-0.034^{* * *}$ & $-0.03^{* * *}$ \\
\hline Factor load. & - & & & - & - & - & $-0.136^{* * *}$ & $-0.126^{* * *}$ \\
\hline \multicolumn{9}{|l|}{ Eq. (5) } \\
\hline Income & $0.688^{* * *}$ & NO & YES & $0.623^{* * *}$ & $0.665^{* * *}$ & $0.66^{* * *}$ & $0.543^{* * *}$ & $0.491^{* * *}$ \\
\hline SA & $0.055^{* * *}$ & (Fig. 2) & (Table A1) & $0.063^{* * *}$ & $0.064^{* * *}$ & $0.064^{* * *}$ & $0.086^{* * *}$ & $0.071^{* * *}$ \\
\hline $\mathrm{RW}_{\mathrm{S}}$ & $0.296^{* * *}$ & & & $0.36^{* * *}$ & $0.324^{* * *}$ & $0.329^{* * *}$ & $0.402^{* * *}$ & $0.472^{* * *}$ \\
\hline Shift(04q1) & - & & & $-0.042^{* * *}$ & $-0.037^{* * *}$ & $-0.037^{* * *}$ & $-0.045^{* * *}$ & $-0.04^{* * *}$ \\
\hline Factor load. & - & & & - & - & - & $-0.054^{* * *}$ & $-0.032^{\dagger}$ \\
\hline \multicolumn{9}{|l|}{ Eq. (6) } \\
\hline Income & $0.845^{* * *}$ & NO & YES & $0.773^{\text {*** }}$ & $0.726^{* * *}$ & $0.718^{* * *}$ & $0.829^{* * *}$ & $0.764^{* * *}$ \\
\hline SA & $0.022^{* * *}$ & (Fig. 2) & (Table A1) & $0.034^{* * *}$ & $0.041^{* * *}$ & $0.041^{* * *}$ & $0.038^{* * *}$ & $0.036^{* * *}$ \\
\hline $\mathrm{RW}_{\mathrm{S}}$ & $0.199^{* * *}$ & & & $0.263^{* * *}$ & $0.3^{* * *}$ & $0.307^{* * *}$ & $0.207^{* * * *}$ & $0.267^{* * *}$ \\
\hline Inflation & $-0.006^{* * *}$ & & & $-0.005^{* * *}$ & $-0.004^{* * *}$ & $-0.004^{* * *}$ & $-0.007^{* * *}$ & $-0.006^{* * *}$ \\
\hline Shift(04q1) & - & & & $-0.034^{* * *}$ & $-0.035^{* * *}$ & $-0.035^{* * *}$ & $-0.035^{* * *}$ & $-0.031^{\text {*** }}$ \\
\hline Factor load. & - & & & - & - & - & $-0.136^{* * *}$ & $-0.117^{* * *}$ \\
\hline \multicolumn{9}{|l|}{ Eq. (7) } \\
\hline Income & $0.733^{* * *}$ & NO & YES & $0.63^{* * *}$ & $0.691^{* * *}$ & $0.721^{* * *}$ & $0.414^{\text {*** }}$ & $0.345^{* * *}$ \\
\hline HW & $0.095^{* *}$ & (Fig. 2) & (Table A1) & $0.161^{\text {*** }}$ & $0.097^{* * *}$ & $0.101^{\text {*** }}$ & $0.277^{* * *}$ & $0.319^{\text {*** }}$ \\
\hline NHW & $0.206^{* * *}$ & & & $0.252^{* * *}$ & $0.256^{* * *}$ & $0.2229^{* * *}$ & $0.34^{* * *}$ & $0.364^{* * *}$ \\
\hline Shift(00q1) & - & & & $-0.039^{* * *}$ & $-0.024^{\dagger}$ & $-0.029^{* *}$ & $-0.068^{* * *}$ & $-0.008^{* * *}$ \\
\hline Factor load. & - & & & - & - & - & 0.009 & 0.002 \\
\hline \multicolumn{9}{|l|}{ Eq. (8) } \\
\hline Income & $0.901^{* * *}$ & NO & NO & & & & & \\
\hline HW & $0.063^{* *}$ & (Fig. 2) & (Table A1) & & & & & \\
\hline NHW & $0.099^{* * *}$ & & & & & & & \\
\hline Inflation & $-0.007^{* * *}$ & & & & & & & \\
\hline Shift(00q1) & - & & & & & & & \\
\hline Factor load. & - & & & & & & & \\
\hline Eq. (9) & & & & & & & & \\
\hline Income & $0.736^{* * *}$ & NO & YES & $0.638^{* * *}$ & $0.658^{* * *}$ & $0.633^{* * *}$ & $0.529^{* * *}$ & $0.503^{* * *}$ \\
\hline $\mathrm{HA}$ & $0.132^{* * *}$ & (Fig. 2) & (Table A1) & $0.21^{* * *}$ & $0.189^{* * *}$ & $0.208^{* * *}$ & $0.226^{\text {*** }}$ & $0.309^{* * *}$ \\
\hline RWH & $0.159^{* * *}$ & & & $0.168^{* * *}$ & $0.171^{* * *}$ & $0.172^{* * *}$ & $0.243^{* * *}$ & $0.178^{* * *}$ \\
\hline Shift(02q1) & - & & & $-0.038^{* * *}$ & $-0.051^{* * *}$ & $-0.054^{* * *}$ & $-0.05^{* * *}$ & $-0.057^{* * *}$ \\
\hline Factor load. & - & & & - & - & - & $-0.054^{* * *}$ & $-0.044^{* * *} \perp$ \\
\hline Eq. (10) & & & & & & & & \\
\hline Income & $0.895^{* * *}$ & NO & YES & $0.802^{* * *}$ & $0.739^{* * *}$ & $0.746^{* * *}$ & $0.772^{* * *}$ & $0.82^{* * *}$ \\
\hline $\mathrm{HA}$ & $0.078^{* *}$ & (Fig. 2) & (Table A1) & $0.157^{\text {*** }}$ & $0.184^{* * *}$ & $0.192^{* * *}$ & $0.158^{* * *}$ & $0.15^{* * *}$ \\
\hline RWH & $0.083^{* * *}$ & & & $0.089^{* * *}$ & $0.095^{* * *}$ & $0.092^{* * *}$ & $0.114^{* * *}$ & $0.084^{* * *}$ \\
\hline Inflation & $-0.007^{* * *}$ & & & $-0.006^{* * *}$ & $-0.005^{* * *}$ & $-0.005^{* * *}$ & $-0.007^{* * *}$ & $-0.008^{* * *}$ \\
\hline Shift(02q1) & - & & & $-0.037^{* * *}$ & $-0.053^{* * *}$ & $-0.054^{* * *}$ & $-0.045^{* * *}$ & $-0.044^{* * *}$ \\
\hline
\end{tabular}


Table 3A (continued)

\begin{tabular}{|c|c|c|c|c|c|c|c|c|}
\hline & \multirow{3}{*}{$\frac{\frac{\text { STEP } 1}{\text { DOLS estimation }}}{\overline{1955 q 1-2010 q 1}}$} & \multirow{3}{*}{$\begin{array}{l}\text { STEP } 2 \\
\text { Cointegration } \\
\text { dynamic test }\end{array}$} & \multirow{3}{*}{$\begin{array}{l}\text { STEP } 2.1 \\
\text { Cointegration }+ \\
\text { shift dummy }\end{array}$} & \multicolumn{5}{|c|}{ STEP 4 (sample 1955q1-2010q1) } \\
\hline & & & & \multicolumn{5}{|c|}{ Cointegration of different methods } \\
\hline & & & & DOLS & $\mathrm{CCR}$ & FMOLS & VAR-MLE & VAR-MLE Restr. \\
\hline Factor load. & - & & & - & - & - & $-0.133^{* * *}$ & $-0.138^{* * *}$ \\
\hline \multicolumn{9}{|l|}{ Eq. (11) } \\
\hline Income & $0.706^{* * *}$ & NO & YES & $0.612^{* * *}$ & $0.673^{* * *}$ & $0.696^{* * *}$ & $0.523^{* * *}$ & $0.476^{* * *}$ \\
\hline LW & $0.038^{* * *}$ & (Fig. 2) & (Table A1) & $0.056^{* * *}$ & $0.074^{* * *}$ & $0.061^{* * *}$ & $0.087^{* * *}$ & $0.096^{* * *}$ \\
\hline IW & $0.272^{* * *}$ & & & $0.357^{* * *}$ & $0.296^{* * *}$ & $0.287^{* * *}$ & $0.411^{* * *}$ & $0.44^{* * *}$ \\
\hline Shift(99q1) & - & & & $-0.039^{* * *}$ & $-0.036^{* *}$ & $-0.035^{* * *}$ & $-0.055^{* * *}$ & $-0.061^{* * *}$ \\
\hline Factor load. & - & & & - & - & - & 0.014 & $\mathbf{0}$ \\
\hline \multicolumn{9}{|l|}{ Eq. (12) } \\
\hline Income & $0.817^{* * *}$ & & & & & & & \\
\hline LW & 0.014 & & & & & & & \\
\hline IW & $0.205^{* * *}$ & & & & & & & \\
\hline Inflation & $-0.005^{* * *}$ & & & & & & & \\
\hline \multicolumn{9}{|l|}{ Eq. (13) } \\
\hline Income & $0.715^{* * *}$ & NO & YES & $0.625^{* * *}$ & $0.68^{* * *}$ & $0.665^{* * *}$ & $0.539^{* * *}$ & $0.485^{* * *}$ \\
\hline LA & $0.047^{* * *}$ & (Fig. 2) & (Table A1) & $0.067^{* * *}$ & $0.084^{* * *}$ & $0.087^{* * *}$ & $0.099^{* * *}$ & $0.112^{* * *}$ \\
\hline RWL & $0.257^{* * *}$ & & & $0.337^{* * *}$ & $0.281^{* * *}$ & $0.292^{* * *}$ & $0.387^{* * *}$ & $0.418^{* * *}$ \\
\hline Shift(99q1) & - & & & $-0.038^{* * *}$ & $-0.036^{* *}$ & $-0.038^{* * *}$ & $-0.053^{* * *}$ & $-0.06^{* * *}$ \\
\hline Factor load. & - & & & - & - & - & 0.014 & $-0.001 \perp$ \\
\hline \multicolumn{9}{|l|}{ Eq. (14) } \\
\hline Income & $0.824^{* * *}$ & & & & & & & \\
\hline LA & 0.021 & & & & & & & \\
\hline RWL & $0.194^{* * *}$ & & & & & & & \\
\hline Inflation & $-0.005^{* * *}$ & & & & & & & \\
\hline
\end{tabular}

Notes: All data are in log and real per capita except for inflation. Deterministic terms: constant and level shift dummy. Shift(98q1), for example, is one from 1998q1 to zero beforehand. Data legend: TW = total net wealth; Income = disposable labor income; SW = stock market net wealth; NSW = non-stock market net wealth; SW = stock market asset; $\mathrm{RW}_{\mathrm{A}}=$ residual net wealth from SA (TW-SA); $\mathrm{HW}=$ house net wealth; $\mathrm{NHW}=$ non-house net wealth; $\mathrm{HA}=$ housing asset; $\mathrm{RW}_{\mathrm{H}}=$ residual net wealth from $\mathrm{HA}$ (TW-HA); $\mathrm{LW}=$ liquid net wealth; IW = illiquid net wealth; $\mathrm{LA}=$ liquid asset; $\mathrm{RW}_{\mathrm{L}}=$ residual net wealth from $\mathrm{LA}(\mathrm{TW}-\mathrm{LA})$. The four estimation procedures used are the dynamic ordinary least squares method (DOLS), the canonical cointegrating regression method (CCR), the fully modified OLS method (FMOLS), and Johansen's VAR-maximum likelihood estimation method (VAR-MLE). Newey-West adjusted t-statistics are reported in parentheses. In the DOLS estimation leads and lags are selected according to HQ criteria; the sample period denotes the range of data before the data points for leads and lags are removed. In the VAR-MLE, the lag length chosen was four, according to the consensus in the empirical literature which uses quarterly data. VAR-MLE Restr. indicates the estimation of the long run relationship imposing restrictions on the adjustment coefficients of other variables. The LR test supports the restrictions for all models except for those denoted with ${ }^{\perp} .{ }^{*}$ indicates significance at the $10 \%$ level; ${ }^{* *}$ indicates significance at the $5 \%$ level; ${ }^{* * *}$ indicates significance at the $1 \%$ level, and ${ }^{\dagger}$ indicates significance at the $12 \%$ level. Terms in bold letters are reported the wrong results which exclude the possibility that the variables in the equation are cointegrated according our logic scheme.

rates became fairly volatile and the MEW mechanism (cash-out effect) exerted its strongest influence on consumption.

\section{Estimation results}

All the statistical results, on a step by step basis, are reported in Tables 3A and 3B. In Fig. 2, the values of the residual ADF test coming from the DOLS estimations conducted in STEP 1 (dynamically extending the sample one quarter at a time) are illustrated, and we compared these values with the critical levels in order to assess if the stationary condition is satisfied. In Table A1 in Appendix A results of the cointegration tests in STEP 2.1 are presented.

From Tables 3A and 3B it emerges that just three models pass all the steps required by the outlined estimation strategy so that their variables can be defined as cointegrated: consumption-labor income-total net wealth (Eq. (1)), consumption-labor income-stock market net wealth-non-stock market net wealth (Eq. (4)), and consumption-labor income-stock market asset-residual net wealth (Eq. (6) )..$^{9}$ The final two models appear to be almost identical, as we can see by comparing the results of various steps and looking at the

\footnotetext{
${ }^{9}$ Eqs. (2), (8), (12) and (14) did not pass the first two steps, showing no cointegration. Eqs. (7), (11) and (13) show a factor loading (in the Johansen-MLE procedure estimation) which is not statistically significant or incorrect in terms of the sign. Eqs. (3), (5), (9) and (10), which show a cointegrating relationship over the whole sample, do not pass the stability test for the coefficient signs over the three subsamples.
}

coefficients that have been estimated. Therefore, we can consider these two equations as comprising only one result. This is because it makes no substantial difference whether we compute stock market values based on just on asset, or if we consider net wealth.

Between the two "surviving" formulations of the consumption function i.e., Eqs. (1) and (4) (or 6), the latter is preferable for empirical and theoretical reasons. As far as the empirical aspect is concerned, we can see that Eq. (4) (or 6) is stable over a longer period of time (see Fig. 2 of the ADF residual tests) before a break occurs in the relationship and fits better consumption. ${ }^{10}$ The most important aspect in empirical terms is the comparison of the estimates of the equations of the subsamples. Eq. (1), which refers to the total net wealth, shows the regression coefficients relative to labor income in the subsamples. The estimates are all significantly higher than the levels estimated for the whole sample (with an approximate range of $0.85-0.92$ in the subsamples, compared to a value of 0.70 over the whole period). This strange behavior of the coefficients is offset by the analogous behavior of the net wealth coefficients of the subsamples, which are always lower than the coefficients obtained for the entire period (with an approximate range of $0.10-0.24$ for the subsamples compared 0.36 value over the entire period). If we add the values of the labor income and net wealth coefficients, this results

\footnotetext{
${ }^{10}$ It is sufficient to compare the sum squared of error (SSE) of the two equations, obtaining a value of 0.02 for the inflation-augmented-disaggregated-wealth specification versus 0.05 for the simple aggregated wealth specification.
} 
Table 3B

Estimation results.

Subsample comparisons.

\begin{tabular}{|c|c|c|c|}
\hline & \multicolumn{3}{|l|}{ STEP 5} \\
\hline & \multicolumn{3}{|c|}{ Subsample comparison } \\
\hline & 1955q1-1980q1 & 1980q1-2010q1 & 1991q1-2010q1 \\
\hline \multicolumn{4}{|l|}{ Eq. (1) } \\
\hline Income & $0.844^{* * *}$ & $0.918^{* * *}$ & $0.847^{* * *}$ \\
\hline TW & $0.103^{* *}$ & $0.237^{* * *}$ & $0.155^{* * *}$ \\
\hline Shift(97q4) & - & $-0.052^{* * *}$ & - \\
\hline Factor load. & - & - & - \\
\hline \multicolumn{4}{|l|}{ Eq. (2) } \\
\hline Income & - & - & - \\
\hline TW & - & - & - \\
\hline Inflation & - & - & - \\
\hline \multicolumn{4}{|l|}{ Eq. (3) } \\
\hline Income & $0.591^{* * *}$ & $0.91^{* * *}$ & $0.992^{* * *}$ \\
\hline SW & $0.028^{* * *}$ & $0.045^{* * *}$ & $0.063^{* * *}$ \\
\hline NSW & $0.392^{* * *}$ & $0.146^{* * *}$ & $-0.039^{* * *}$ \\
\hline Shift(04q1) & - & $-0.031^{* *}$ & - \\
\hline Factor load. & - & - & - \\
\hline \multicolumn{4}{|l|}{ Eq. (4) } \\
\hline Income & $0.682^{* * *}$ & $0.785^{* * *}$ & $0.864^{* * *}$ \\
\hline SW & $0.016^{\dagger}$ & $0.052^{* * *}$ & $0.064^{* * *}$ \\
\hline NSW & $0.347^{* * *}$ & $0.152^{* * *}$ & $0.043^{* *}$ \\
\hline Inflation & $-0.004^{* * *}$ & $-0.007^{* * *}$ & $-0.003^{* *}$ \\
\hline Shift(04q1) & - & $-0.015^{* *}$ & - \\
\hline Factor load. & - & - & - \\
\hline \multicolumn{4}{|l|}{ Eq. (5) } \\
\hline Income & $0.595^{* * *}$ & $0.906^{* * *}$ & $0.979^{* * *}$ \\
\hline SA & $0.036^{* * *}$ & $0.049^{* * *}$ & $0.065^{* * *}$ \\
\hline $\mathrm{RW}_{\mathrm{S}}$ & $0.384^{* * *}$ & $0.144^{* * *}$ & $-0.034^{*}$ \\
\hline Shift(04q1) & - & $-0.031^{* *}$ & - \\
\hline Factor load. & - & - & - \\
\hline \multicolumn{4}{|l|}{ Eq. (6) } \\
\hline Income & $0.693^{* * *}$ & $0.781^{* * *}$ & $0.853^{* * *}$ \\
\hline SA & $0.022^{* *}$ & $0.057^{* * * *}$ & $0.067^{* * *}$ \\
\hline $\mathrm{RW}_{\mathrm{S}}$ & $0.331^{* * * *}$ & $0.149^{* * *}$ & $0.046^{*}$ \\
\hline Inflation & $-0.003^{* * *}$ & $-0.007^{* * *}$ & $-0.003^{*}$ \\
\hline Shift(04q1) & - & $-0.015^{* *}$ & - \\
\hline Factor load. & - & - & - \\
\hline \multicolumn{4}{|l|}{ Eq. (7) } \\
\hline Income & - & - & - \\
\hline HW & - & - & - \\
\hline NHW & - & - & - \\
\hline Shift(00q1) & - & - & - \\
\hline Factor load. & - & - & - \\
\hline \multicolumn{4}{|l|}{ Eq. (8) } \\
\hline Income & - & - & - \\
\hline HW & - & - & - \\
\hline NHW & - & - & - \\
\hline Inflation & - & - & - \\
\hline Shift(00q1) & - & - & - \\
\hline Factor load. & - & - & - \\
\hline \multicolumn{4}{|l|}{ Eq. (9) } \\
\hline Income & $0.68^{* * *}$ & $1.11^{* * *}$ & $1.11^{* * *}$ \\
\hline HA & $0.209^{* * *}$ & $0.092^{* * *}$ & $-0.078^{* * *}$ \\
\hline $\mathrm{RW}_{\mathrm{H}}$ & $0.052^{*}$ & 0.036 & $0.095^{* * *}$ \\
\hline Shift(02q1) & - & $-0.062^{* * *}$ & - \\
\hline Factor load. & - & - & - \\
\hline \multicolumn{4}{|l|}{ Eq. (10) } \\
\hline Income & $0.754^{* * *}$ & $0.918^{* * * *}$ & $0.96^{* * * *}$ \\
\hline HA & $0.183^{* * *}$ & $0.059^{* *}$ & -0.021 \\
\hline $\mathrm{RW}_{\mathrm{H}}$ & 0.015 & $0.094^{* * *}$ & $0.113^{* * *}$ \\
\hline Inflation & $-0.002^{*}$ & $-0.007^{* * *}$ & $-0.004^{*}$ \\
\hline Shift(02q1) & - & $-0.024^{* *}$ & - \\
\hline Factor load. & - & - & - \\
\hline
\end{tabular}

Table 3B (continued)

\begin{tabular}{|c|c|c|c|}
\hline & \multicolumn{3}{|l|}{ STEP 5} \\
\hline & \multicolumn{3}{|c|}{ Subsample comparison } \\
\hline & 1955q1-1980q1 & 1980q1-2010q1 & 1991q1-2010q1 \\
\hline \multicolumn{4}{|l|}{ Eq. (11) } \\
\hline Income & - & - & - \\
\hline LW & - & - & - \\
\hline IW & - & - & - \\
\hline Shift(99q1) & - & - & - \\
\hline Factor load. & - & - & - \\
\hline \multicolumn{4}{|l|}{ Eq. (12) } \\
\hline Income & - & - & - \\
\hline LW & - & - & - \\
\hline IW & - & - & - \\
\hline Inflation & - & - & - \\
\hline \multicolumn{4}{|l|}{ Eq. (13) } \\
\hline Income & - & - & - \\
\hline LA & - & - & - \\
\hline $\mathrm{RW}_{\mathrm{L}}$ & - & - & - \\
\hline Shift(99q1) & - & - & - \\
\hline Factor load. & - & - & - \\
\hline \multicolumn{4}{|l|}{ Eq. (14) } \\
\hline Income & - & - & - \\
\hline LA & - & - & - \\
\hline $\mathrm{RW}_{\mathrm{L}}$ & - & - & - \\
\hline Inflation & - & - & - \\
\hline
\end{tabular}

Notes: See notes of Table $3 \mathrm{~A}$

in a fairly stable value of approximately 1.05 , independent of the period of time in which we estimated the consumption function. That means that a sort of compensation occurs between labor income and net wealth contribution to consumption. This suggests that the two effects are not entirely separate, and that they interfere with each other. This problem does not occur with Eqs. (4) or (6), where each coefficient over the whole sample can be seen as an average of the values of the coefficient over the subsamples. In the last case, only the variability of wealth components is high, especially with regard to the subsample 1991-2010, showing a significantly lower value for non-stock coefficient. ${ }^{11}$ From a theoretical point of view, a more complex specification capable of the successful interpretation of the evolution of the main components of wealth would be preferable. Recent experience indicates a significantly different evolution of the stock market and of the housing market, a trend which seems set to continue in the future. In this case it is very important, in our opinion, to have a more detailed estimation of the consumption function which is able to quantify the individual contributions of the main components of wealth and not only the average effect of the total amount of wealth on consumption. ${ }^{12}$

After having identified the best equation, we investigated the presence of an asymmetrical short term effect of the nominal interest rate on consumption. This approach involved estimation of ECM (with the error term of the long term relationship represented by Eq. $(4)^{13}$ ) with asymmetrical short term dynamics of the interest

\footnotetext{
11 The stock market wealth coefficient, over the subsample 195-1980, is at the limit for statistical significance with a p-value of 0.11 . This does not make a dent in the result because Eq. (6) shows a significant value for this variable in the same subsample.

12 The marginal propensity to consume (relative to Model 4) out of the two wealth components and income is as follows: $\mathrm{mpc}_{\mathrm{INC}}=0.982, \mathrm{mpc}_{\mathrm{SW}}=0.029$, mpc$\mathrm{Nsw}=0.071$. These values are in line with other empirical studies conducted on the consumption function.

${ }^{13}$ A very similar result occurs if we apply the error of the long run relationship of Model number 6 .
} 
rate. The results of our estimation are shown in Table 4. As we expected, the magnitude of the effect of a negative change in the nominal interest rate $\left(D^{-} \times \Delta i\right)$ is twice that of a positive change

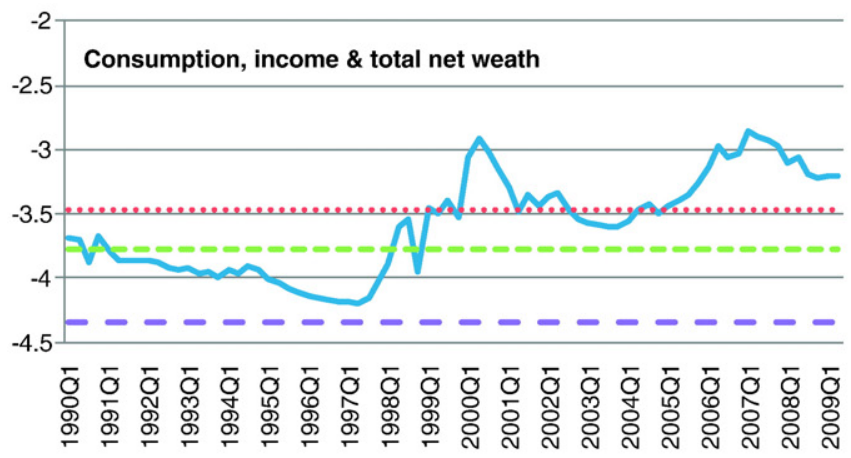

- t-statistic $\cdots . .$. CV $10 \%---$ CV $5 \%--$ CV $1 \%$

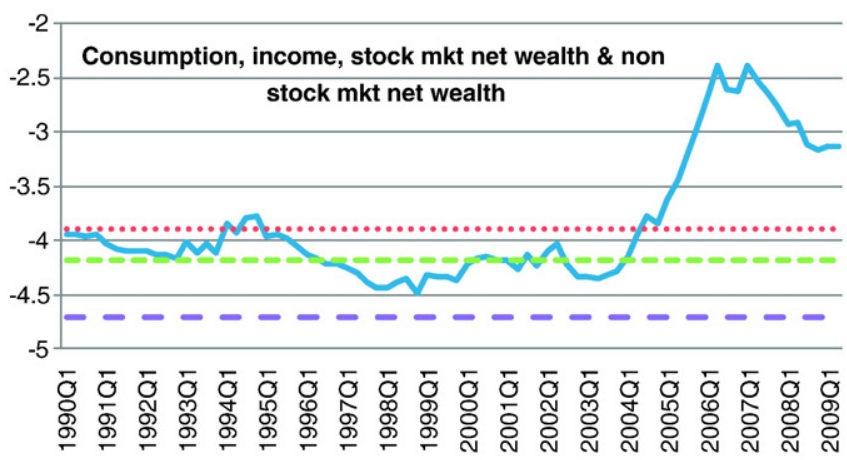

t-statistic $\cdots . .$. CV $10 \%---$ CV $5 \%-$ CV $1 \%$

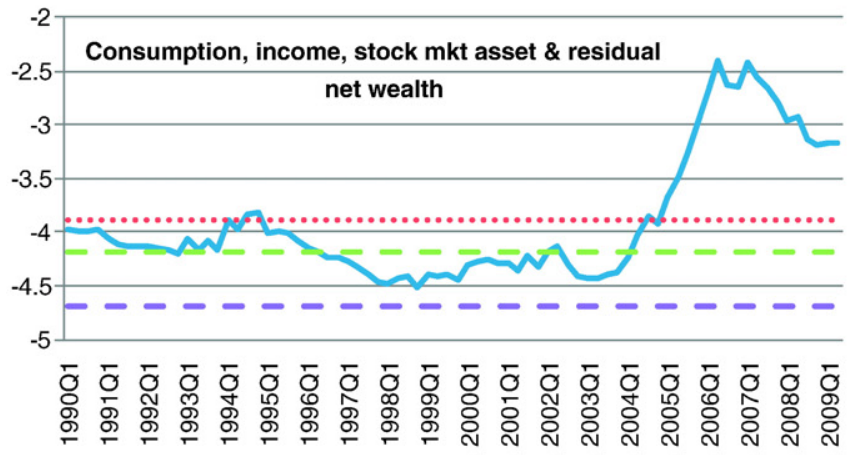

t-statistic $\cdots . .$. CV $10 \%-$ - CV $5 \%-$ CV $1 \%$

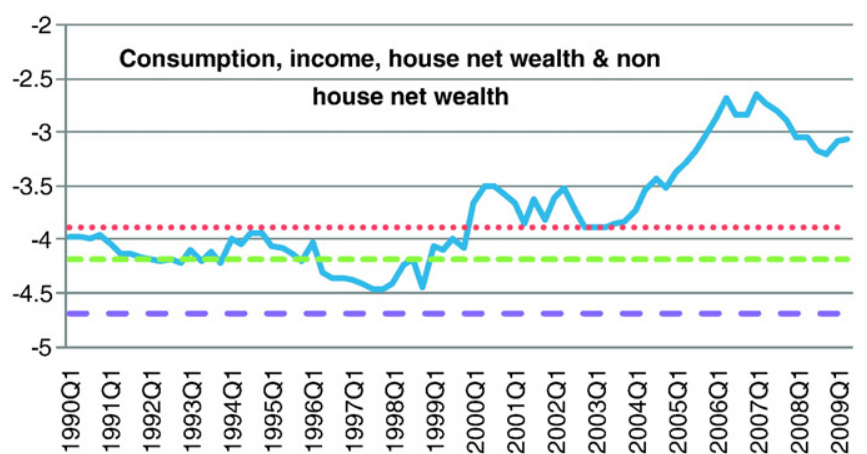

- t-statistic $\cdots . .$. CV $10 \%---$ CV $5 \%-$ CV $1 \%$
$\left(D^{+} \times \Delta i\right)$. In addition, a positive change is not statistically significant confirming our view that the cash-out effect explicates its effect when interest rates decrease.

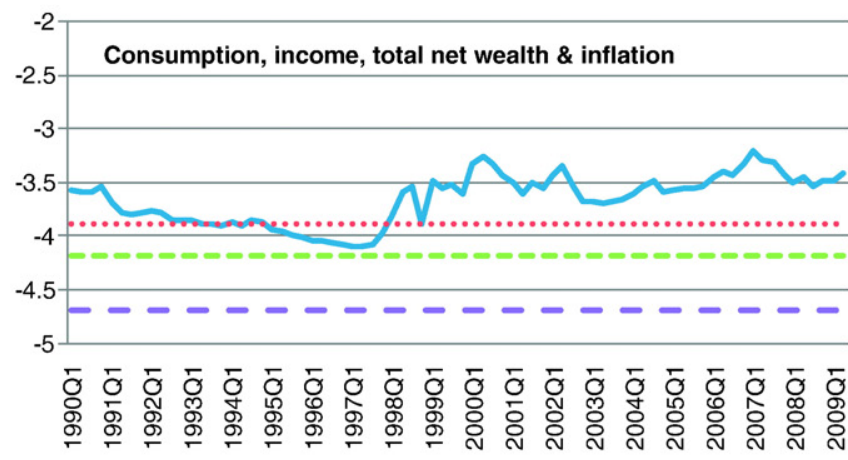

- t-statistic $\cdots .$. CV $10 \%---$ CV $5 \%--$ CV $1 \%$

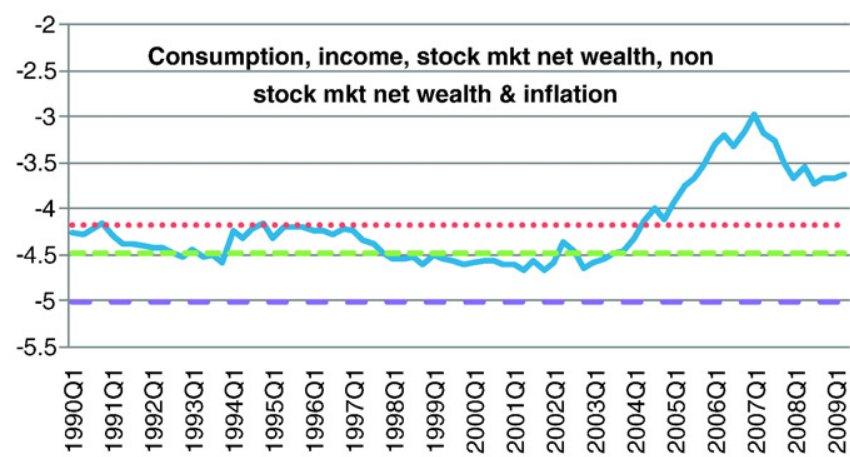

- -statistic $\cdots .$. CV $10 \%---$ CV $5 \%-$ CV $1 \%$

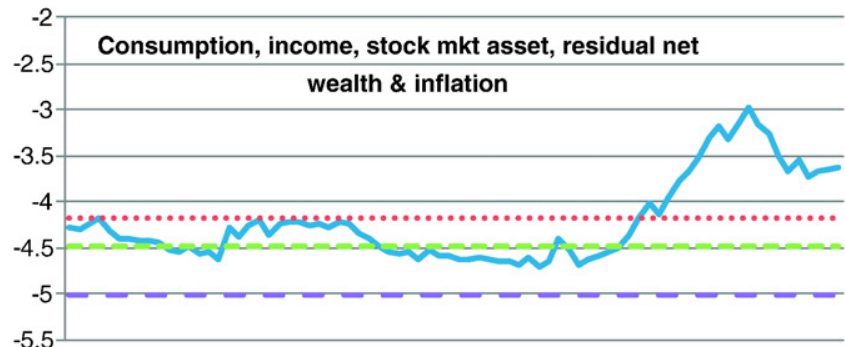

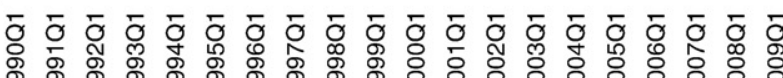
Ф

t-statistic $\cdots . .$. CV $10 \%---$ CV $5 \%-$ CV $1 \%$

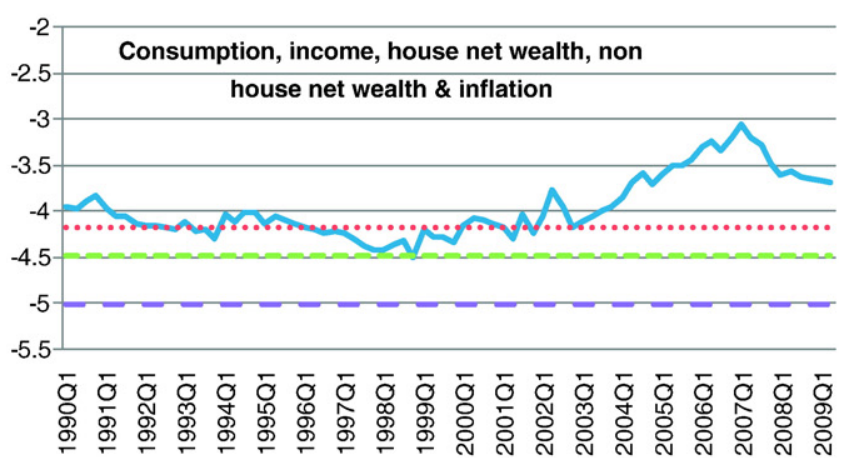

- t-statistic $\cdots . .$. CV $10 \%---$ CV $5 \%-$ CV $1 \%$

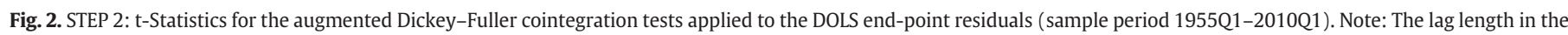
ADF residual test was chosen according to the AIC criteria. 


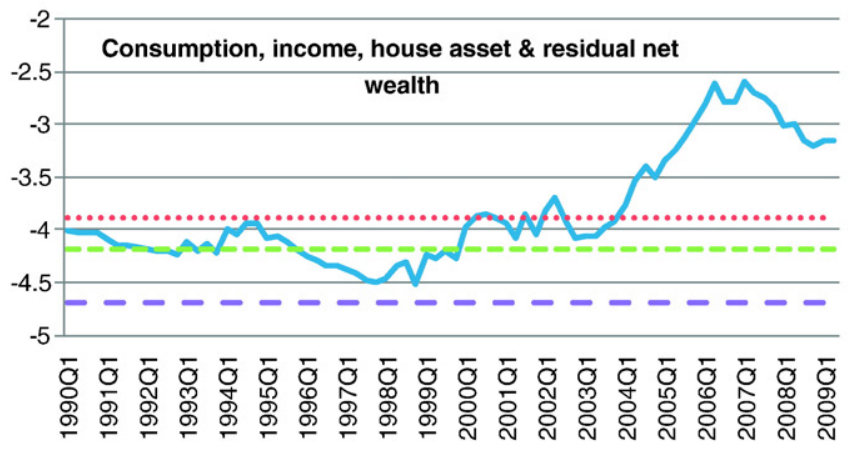

t-statistic $\cdots . .$. CV $10 \%---$ CV $5 \%-$ CV $1 \%$

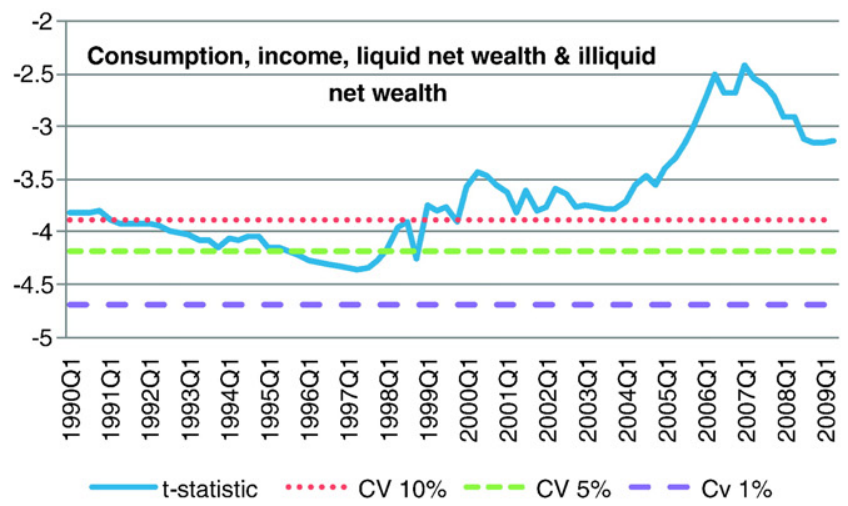

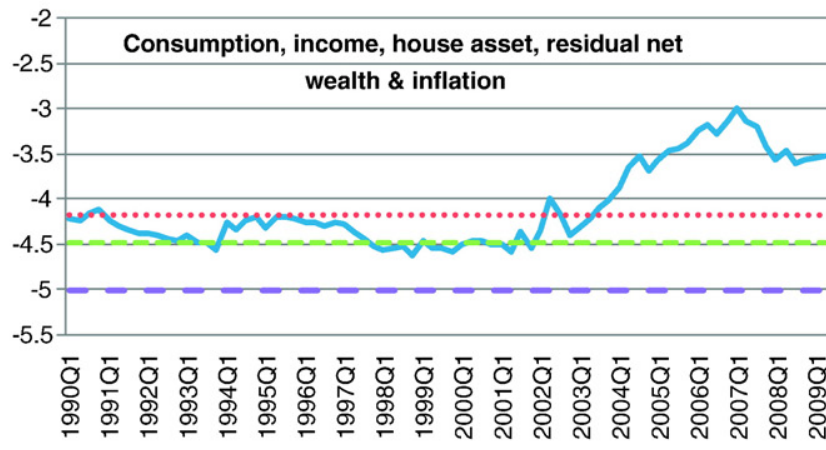

- t-statistic $\cdots .$. CV $10 \%---$ CV $5 \%-$ CV $1 \%$

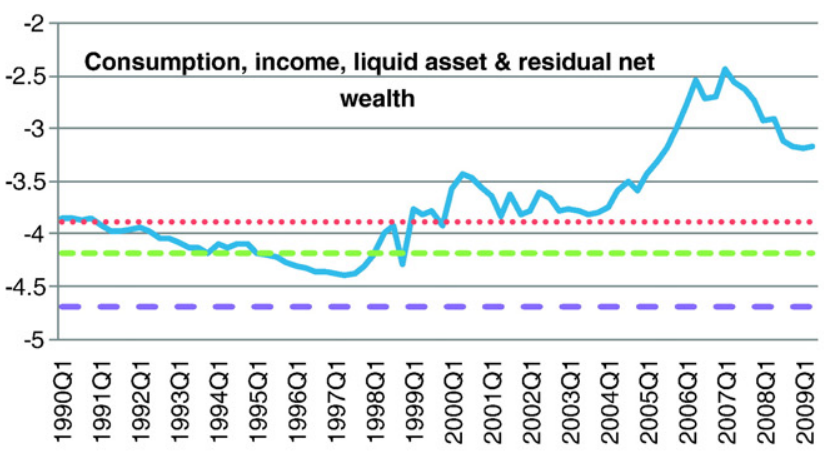

t-statistic $\cdots . .$. CV $10 \%---$ CV $5 \%-$ CV $1 \%$

Fig. 2 (continued).

\section{Conclusions}

This article examined different consumption function formulations for the US economy from the 1950s to the present day. Utilizing a structured estimation strategy, we found that the inclusion of a shift in the intercept and adding inflation as an additional explanatory variable to the long run relationship between consumption, labor income, stock wealth, non-stock wealth has yielded a stable relationship. In particular, the inflation rate seems to have played an important role in stabilizing the long term relationship after the 1990s. The period between 1991 and 2009 was characterized by the cash-

Table 4

ECM estimation of consumption, stock market wealth, non-stock market net wealth and inflation.

\begin{tabular}{lll}
\hline Dependent variable & Coefficient & t-Statistic \\
\hline$E C T_{t-1}$ & -0.14 & 3.23 \\
Const. & 0.001 & 2.08 \\
$\Delta y_{t-1}$ & 0.169 & 3.72 \\
$\Delta c_{t-1}$ & 0.139 & 2.03 \\
$\Delta c_{t-2}$ & 0.116 & 1.8 \\
$\Delta c_{t-3}$ & 0.169 & 2.67 \\
$\Delta s w_{t-1}$ & 0.013 & 2.84 \\
$\Delta s w_{t-2}$ & -0.007 & 1.38 \\
$\Delta s w_{t-3}$ & 0.009 & 1.87 \\
$\Delta n s w_{t-2}$ & 0.206 & 4.3 \\
$\Delta n s w_{t-3}$ & -0.156 & 3.18 \\
$D^{+} \times \Delta i_{t-1}$ & -0.001 & 1.14 \\
$D^{-} \times \Delta i_{t-1}$ & -0.002 & 3.04 \\
Dus0Q2 & -0.025 & 4.43 \\
Adjusted R-squared & 0.399 & \\
Durbin-Watson stat & 1.913 & \\
\hline
\end{tabular}

Notes: Normality test: Jarque-Bera $=4.017$ [0.134]; Heteroskedasticity test: BreuschPagan-Godfrey $=0.776$ [0.685]. Du80Q2 is an impulse dummy which is one in the second quarter of 1980 , and zero elsewhere. $D^{+} \times \Delta i$ and $D^{-} \times \Delta i$ are positive and negative changes in the interest rate respectively. out effect caused by the MEW effect and inflation. Finally, this study also found that the effect of the nominal interest rate on consumption is asymmetrical. Declines in the interest rate had larger effects on consumption than increases in the rate of interest. However, the effects of only decreases in the rate of interest are found to be statistically significant. We hope that our study will encourage further investigations into the stability of the US long run consumption function as well as consumption functions of other countries.

\section{Appendix A}

In this section, we will provide a description of the data used in our analysis. Data relating to consumption, net wealth, and income are deflated by PCE using the chained price index for PCE. The same data are also expressed in per capita units by dividing real data by the population measure (POP). The source of the price deflator and the population measure is the Bureau of Economic Analysis (BEA).

Consumption $(C)$ Consumption is measured as the total PCE including durable and non-durable goods and services. The quarterly data are seasonally adjusted at annual rates in billions of dollars. Our source is the BEA.

Disposable labor income $(Y)$ Disposable labor income is defined as wage and salary disbursement (NIPA Table 2.1, line 2) + transfers to person (line 16) + employer contributions to employee pension and insurance funds (line 7) - contributions for government social insurance (line 24) - labor taxes (line 25). Taxes are defined as: [wages and salary disbursement/(wages and salary disbursement + proprietor's income + rental income + personal income receipts on assets $)] \times$ personal current taxes. The quarterly data are seasonally adjusted at annual rates in billions of dollars. Our source is the BEA.

Net wealth All wealth measures are constructed from the flowof-funds accounts of the Boards of Governors of the Federal Reserve System and are expressed on an end-of-period basis. 


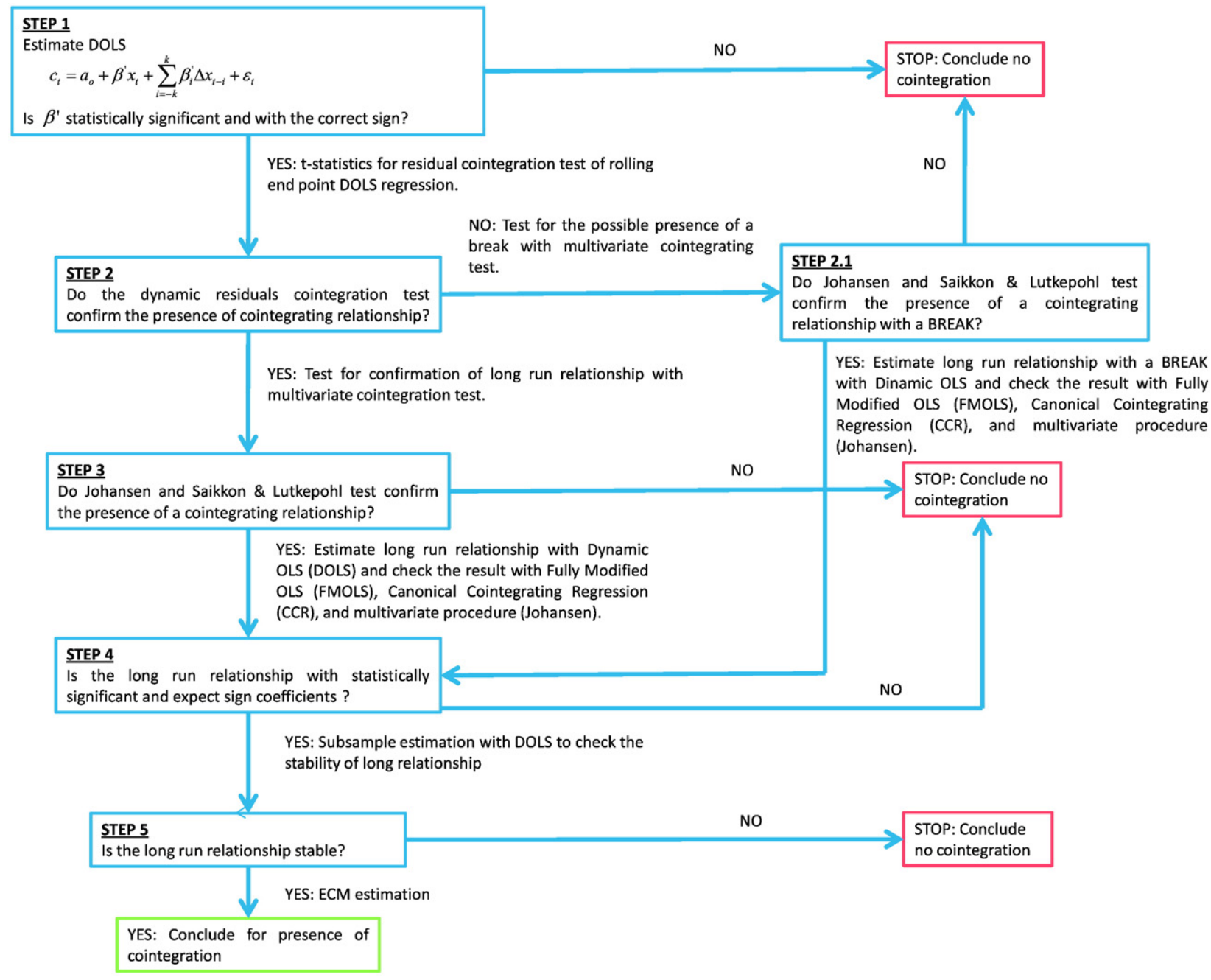

Fig. A1. Decision-making strategy for empirical estimation. Source: Our elaboration.

Therefore, throughout this paper the $\mathrm{t}-1$ value of the flow-of-funds data is associated with period t wealth in order to obtain a start-of-period measure. The measure of asset employed excludes consumption durables since we are considering total consumer expenditure. Our sources are the flow-of-funds tables.

Total net wealth $($ TW $)=$ Total assets (Table B. 100) - total liabilities (Table B. 100).

Stock market assets $(S A)=$ Corporate equities + corporate equities held in mutual fund shares + corporate equities held in life insurance reserves + corporate equities held in pension fund reserves.

Corporate equities held in mutual fund shares=mutual funds shares (Table B. 100) $\times$ [mutual funds held in corporate equities (Table L.122)/total mutual funds financial assets (Table L.122)].

Corporates held in life insurance reserves $=$ life insurance reserves (Table B. 100) $\times$ [life insurance reserves held in corporate equities (Table L.117)/total life insurance financial assets (Table L.117)].

Corporate held in pension fund reserves=pension fund reserves (Table B. 100) $\times[$ (private pension funds held in corporate equities (Table L. 118) + state and local government retirement funds held in corporate equities (Table L.119) + federal government retirement funds held in corporate equities (Table L. 120))/ (total private pension funds assets (Table L. 118) + total state and local government retirement funds assets (Table L. 119) + total federal government retirement funds net acquisition of financial assets (Table L. 120))].

Non-stock assets $=$ total assets - stock market assets.
Stock market liabilities $=[$ stock market assets $/$ (total assets - housing assets (Table B. 100)) $\times($ total liabilities (Table B. 100) - home mortgages (Table B. 100)).

Stock market net wealth $(S W)=$ Stock market assets - stock market liabilities.

Non-stock market net wealth $(N S W)=$ Total net wealth - stock market net wealth

Residual net wealth from stock market asset $\left(R W_{\mathbf{S}}\right)=\mathrm{TW}-\mathrm{SA}$

Housing net wealth $(H W)=$ Housing assets - home mortgages

Housing assets $(H A)=$ Table B. 100

Non-housing net wealth $(N H W)=$ Total net wealth - housing net wealth

Residual net wealth from housing asset $\left(R W_{H}\right)=\mathrm{TW}-\mathrm{HA}$

Liquid assets $(L A)=$ Corporate equities + corporate equities held in mutual fund shares + total deposits (Table B. 100) - foreign deposits (Table B. 100)

Liquid liabilities $=[$ liquid assets $/$ (total assets - housing assets (Table B. 100)) $\times($ Total liabilities (Table B. 100) - home mortgages (Table B. 100))

Liquid net wealth $(L W)=$ Liquid assets - liquid liabilities Illiquid net wealth $(I W)=$ Total net wealth - liquid net wealth Residual net wealth from stock liquid asset $\left(R W_{L}\right)=\mathrm{TW}-\mathrm{LA}$

Nominal fed funds rate (effective) is taken from the Federal Reserve Economic Data (FRED).

Inflation is calculated as the CPI percentage change from the same quarter in the previous year. Source: Bureau of Labour Statistics. 
Table A1

Cointegration tests (STEP 2.1).

\begin{tabular}{|c|c|c|c|c|c|}
\hline Model & $\begin{array}{l}\text { Deterministic } \\
\text { term }\end{array}$ & $\begin{array}{l}\text { No. of } \\
\text { lags }\end{array}$ & $\mathrm{r}_{0}$ & $\begin{array}{l}\text { Test } \\
\text { value }\end{array}$ & $\begin{array}{l}\mathrm{p} \\
\text { value }\end{array}$ \\
\hline \multicolumn{6}{|c|}{ Johansen trace test (1955q1-2010q1) } \\
\hline \multirow{12}{*}{$\begin{array}{l}\text { Consumption, income and } \\
\text { total net wealth }\end{array}$} & \multirow[t]{12}{*}{$c$, shift(98q1) } & \multirow[t]{3}{*}{1} & 0 & 139.93 & 0 \\
\hline & & & 1 & 22.45 & 0.11 \\
\hline & & & 2 & 3.97 & 0.7 \\
\hline & & \multirow[t]{3}{*}{2} & 0 & 69.73 & 0 \\
\hline & & & 1 & 22.83 & 0.1 \\
\hline & & & 2 & 6.6 & 0.37 \\
\hline & & \multirow[t]{3}{*}{3} & 0 & 59.84 & 0 \\
\hline & & & 1 & 23.12 & 0.09 \\
\hline & & & 2 & 7.01 & 0.33 \\
\hline & & \multirow[t]{3}{*}{4} & 0 & 50.92 & 0 \\
\hline & & & 1 & 24.92 & 0.05 \\
\hline & & & 2 & 6.85 & 0.34 \\
\hline \multirow{16}{*}{$\begin{array}{l}\text { Consumption, income, stock } \\
\text { market (mkt) net wealth } \\
\text { and non-stock mkt net } \\
\text { wealth }\end{array}$} & \multirow[t]{16}{*}{$c, \operatorname{shift}(04 q 1)$} & 1 & 0 & 177.21 & 0 \\
\hline & & & 1 & 33.31 & 0.26 \\
\hline & & & 2 & 9.79 & 0.88 \\
\hline & & & 3 & 2.65 & 0.83 \\
\hline & & 2 & 0 & 91.43 & 0 \\
\hline & & & 1 & 35.24 & 0.18 \\
\hline & & & 2 & 15.7 & 0.43 \\
\hline & & & 3 & 4.59 & 0.55 \\
\hline & & 3 & 0 & 79.93 & 0 \\
\hline & & & 1 & 38.48 & 0.09 \\
\hline & & & 2 & 17.89 & 0.28 \\
\hline & & & 3 & 5.09 & 0.49 \\
\hline & & 4 & 0 & 85.46 & 0 \\
\hline & & & 1 & 44.61 & 0.02 \\
\hline & & & 2 & 20.43 & 0.15 \\
\hline & & & 3 & 5.89 & 0.39 \\
\hline Consumption, income, & $c, \operatorname{shift}(04 q 1)$ & 1 & 0 & 245.69 & 0 \\
\hline stock mkt net wealth, & & & 1 & 69.34 & 0.01 \\
\hline non-stock mkt net & & & 2 & 39.71 & 0.07 \\
\hline wealth and inflation & & & 3 & 15.54 & 0.45 \\
\hline & & & 4 & 3.51 & 0.71 \\
\hline & & 2 & 0 & 135.69 & 0 \\
\hline & & & 1 & 65.12 & 0.02 \\
\hline & & & 2 & 38.91 & 0.08 \\
\hline & & & 3 & 17.26 & 0.32 \\
\hline & & & 4 & 6.36 & 0.34 \\
\hline & & 3 & 0 & 128.1 & 0 \\
\hline & & & 1 & 67.11 & 0.02 \\
\hline & & & 2 & 38.54 & 0.09 \\
\hline & & & 3 & 17.57 & 0.3 \\
\hline & & & 4 & 6 & 0.38 \\
\hline & & 4 & 0 & 140.48 & 0 \\
\hline & & & 1 & 87.1 & 0 \\
\hline & & & 2 & 44.72 & 0.02 \\
\hline & & & 3 & 17.85 & 0.28 \\
\hline & & & 4 & 5.67 & 0.42 \\
\hline Consumption, income, & $c, \operatorname{shift}(04 q 1)$ & 1 & 0 & 176.71 & 0 \\
\hline stock mkt asset and & & & 1 & 33.85 & 0.23 \\
\hline residual net wealth & & & 2 & 9.73 & 0.88 \\
\hline & & & 3 & 2.57 & 0.84 \\
\hline & & 2 & 0 & 92.41 & 0 \\
\hline & & & 1 & 36.01 & 0.16 \\
\hline & & & 2 & 15.97 & 0.41 \\
\hline & & & 3 & 4.55 & 0.56 \\
\hline & & 3 & 0 & 80.52 & 0 \\
\hline & & & 1 & 38.55 & 0.09 \\
\hline & & & 2 & 17.95 & 0.28 \\
\hline & & & 3 & 5.08 & 0.49 \\
\hline & & 4 & 0 & 86.25 & 0 \\
\hline & & & 1 & 45.1 & 0.02 \\
\hline & & & 2 & 20.46 & 0.15 \\
\hline & & & 3 & 5.82 & 0.4 \\
\hline Consumption, income, stock & $c$, shift $(04 q 1)$ & 1 & 0 & 245.41 & 0 \\
\hline mkt asset, residual net & & & 1 & 69.95 & 0.01 \\
\hline wealth and inflation & & & 2 & 40.05 & 0.07 \\
\hline & & & 3 & 15.46 & 0.45 \\
\hline & & & 4 & 3.42 & 0.72 \\
\hline & & 2 & 0 & 136.97 & 0 \\
\hline & & & 1 & 66.12 & 0.02 \\
\hline & & & 2 & 39.76 & 0.07 \\
\hline
\end{tabular}

Table A1 (continued)

\begin{tabular}{|c|c|c|c|c|c|}
\hline Model & $\begin{array}{l}\text { Deterministic } \\
\text { term }\end{array}$ & $\begin{array}{l}\text { No. of } \\
\text { lags }\end{array}$ & $\mathrm{r}_{0}$ & $\begin{array}{l}\text { Test } \\
\text { value }\end{array}$ & $\begin{array}{l}\mathrm{p} \\
\text { value }\end{array}$ \\
\hline & & & 3 & 17.55 & 0.3 \\
\hline & & & 4 & 6.34 & 0.34 \\
\hline & & 3 & 0 & 128.63 & 0 \\
\hline & & & 1 & 67.34 & 0.01 \\
\hline & & & 2 & 38.64 & 0.09 \\
\hline & & & 3 & 17.67 & 0.29 \\
\hline & & & 4 & 6.01 & 0.38 \\
\hline & & 4 & 0 & 141.41 & 0 \\
\hline & & & 1 & 87.43 & 0 \\
\hline & & & 2 & 45.1 & 0.02 \\
\hline & & & 3 & 17.94 & 0.28 \\
\hline & & & 4 & 5.65 & 0.42 \\
\hline \multirow{16}{*}{$\begin{array}{l}\text { Consumption, income, } \\
\text { house net wealth } \\
\text { and non-house net } \\
\text { wealth }\end{array}$} & $c$, shift(00q1) & 1 & 0 & 154.55 & 0 \\
\hline & & & 1 & 30.72 & 0.43 \\
\hline & & & 2 & 13.46 & 0.67 \\
\hline & & & 3 & 3.59 & 0.74 \\
\hline & & 2 & 0 & 83.72 & 0 \\
\hline & & & 1 & 30.82 & 0.43 \\
\hline & & & 2 & 14.09 & 0.62 \\
\hline & & & 3 & 6.01 & 0.42 \\
\hline & & 3 & 0 & 76.92 & 0 \\
\hline & & & 1 & 33.92 & 0.26 \\
\hline & & & 2 & 17.13 & 0.37 \\
\hline & & & 3 & 6.38 & 0.37 \\
\hline & & 4 & 0 & 78.9 & 0 \\
\hline & & & 1 & 42.64 & 0.04 \\
\hline & & & 2 & 17.77 & 0.33 \\
\hline & & & 3 & 7.24 & 0.29 \\
\hline \multirow{16}{*}{$\begin{array}{l}\text { Consumption, income, } \\
\text { house asset and } \\
\text { residual net wealth }\end{array}$} & $c$, shift $(02 q 1)$ & 1 & 0 & 161.44 & 0 \\
\hline & & & 1 & 24.73 & 0.76 \\
\hline & & & 2 & 8.64 & 0.94 \\
\hline & & & 3 & 2.29 & 0.88 \\
\hline & & 2 & 0 & 83.41 & 0 \\
\hline & & & 1 & 28.59 & 0.54 \\
\hline & & & 2 & 12.4 & 0.73 \\
\hline & & & 3 & 4.02 & 0.66 \\
\hline & & 3 & 0 & 76.99 & 0 \\
\hline & & & 1 & 35.58 & 0.26 \\
\hline & & & 2 & 15.33 & 0.49 \\
\hline & & & 3 & 6.39 & 0.35 \\
\hline & & 4 & 0 & 79.74 & 0 \\
\hline & & & 1 & 42.06 & 0.04 \\
\hline & & & 2 & 18.64 & 0.26 \\
\hline & & & 3 & 7.57 & 0.25 \\
\hline \multirow{20}{*}{$\begin{array}{l}\text { Consumption, income, } \\
\text { houseasset, residual } \\
\text { net wealth and inflation }\end{array}$} & $c, \operatorname{shift}(02 q 1)$ & 1 & 0 & 236.27 & 0 \\
\hline & & & 1 & 57.19 & 0.13 \\
\hline & & & 2 & 26.67 & 0.65 \\
\hline & & & 3 & 12.72 & 0.7 \\
\hline & & & 4 & 2.22 & 0.89 \\
\hline & & 2 & 0 & 133.98 & 0 \\
\hline & & & 1 & 59.3 & 0.09 \\
\hline & & & 2 & 30.92 & 0.4 \\
\hline & & & 3 & 14.4 & 0.57 \\
\hline & & & 4 & 4.78 & 0.55 \\
\hline & & 3 & 0 & 124.42 & 0 \\
\hline & & & 1 & 62.6 & 0.05 \\
\hline & & & 2 & 34.41 & 0.23 \\
\hline & & & 3 & 15.55 & 0.47 \\
\hline & & & 4 & 7.43 & 0.26 \\
\hline & & 4 & 0 & 139.68 & 0 \\
\hline & & & 1 & 85.44 & 0 \\
\hline & & & 2 & 44.31 & 0.02 \\
\hline & & & 3 & 18.75 & 0.25 \\
\hline & & & 4 & 7.57 & 0.25 \\
\hline \multirow{10}{*}{$\begin{array}{l}\text { Consumption, income, } \\
\text { liquid net wealth and } \\
\text { illiquid net wealth }\end{array}$} & $c, \operatorname{shift}(99 q 1)$ & 1 & 0 & 171.98 & 0 \\
\hline & & & 1 & 33.75 & 0.28 \\
\hline & & & 2 & 13.55 & 0.67 \\
\hline & & & 3 & 4.13 & 0.67 \\
\hline & & 2 & 0 & 96.33 & 0 \\
\hline & & & 1 & 37.3 & 0.14 \\
\hline & & & 2 & 18.11 & 0.31 \\
\hline & & & 3 & 6.66 & 0.35 \\
\hline & & 3 & 0 & 92.06 & 0 \\
\hline & & & 1 & 40.53 & 0.07 \\
\hline
\end{tabular}

(continued on next page) 
Table A1 (continued)

\begin{tabular}{|c|c|c|c|c|c|}
\hline Model & $\begin{array}{l}\text { Deterministic } \\
\text { term }\end{array}$ & $\begin{array}{l}\text { No. of } \\
\text { lags }\end{array}$ & $\mathrm{r}_{0}$ & $\begin{array}{l}\text { Test } \\
\text { value }\end{array}$ & $\begin{array}{l}\mathrm{p} \\
\text { value }\end{array}$ \\
\hline \multirow{22}{*}{$\begin{array}{l}\text { Consumption, income, } \\
\text { liquid asset and residual } \\
\text { net wealth }\end{array}$} & \multirow{22}{*}{$c, \operatorname{shift}(99 q 1)$} & \multirow{5}{*}{4} & 2 & 19.39 & 0.23 \\
\hline & & & 3 & 7.02 & 0.32 \\
\hline & & & 0 & 89.43 & 0 \\
\hline & & & 1 & 50.38 & 0 \\
\hline & & & 2 & 22.32 & 0.11 \\
\hline & & & 3 & 9.12 & 0.16 \\
\hline & & \multirow[t]{4}{*}{1} & 0 & 172.1 & 0 \\
\hline & & & 1 & 35.28 & 0.21 \\
\hline & & & 2 & 14.08 & 0.63 \\
\hline & & & 3 & 4.44 & 0.63 \\
\hline & & \multirow[t]{4}{*}{2} & 0 & 97.36 & 0 \\
\hline & & & 1 & 38.01 & 0.12 \\
\hline & & & 2 & 18.8 & 0.27 \\
\hline & & & 3 & 6.66 & 0.35 \\
\hline & & \multirow[t]{4}{*}{3} & 0 & 93.12 & 0 \\
\hline & & & 1 & 40.69 & 0.07 \\
\hline & & & 2 & 19.83 & 0.21 \\
\hline & & & 3 & 7.02 & 0.32 \\
\hline & & \multirow[t]{4}{*}{4} & 0 & 89.61 & 0 \\
\hline & & & 1 & 50.19 & 0 \\
\hline & & & 2 & 22.5 & 0.11 \\
\hline & & & 3 & 8.86 & 0.17 \\
\hline \multicolumn{6}{|l|}{$\begin{array}{l}\text { Saikkonen and Lutkepohl } \\
\text { test (1955q1-2010q1) }\end{array}$} \\
\hline \multirow{12}{*}{$\begin{array}{l}\text { Consumption, income and } \\
\text { total net wealth }\end{array}$} & $c, \operatorname{shift}(98 q 1)$ & 1 & 0 & 101.87 & 0 \\
\hline & & & 1 & 13.07 & 0.04 \\
\hline & & & 2 & 1.76 & 0.21 \\
\hline & & 2 & 0 & 48.78 & 0 \\
\hline & & & 1 & 9.2 & 0.16 \\
\hline & & & 2 & 0.93 & 0.38 \\
\hline & & 3 & 0 & 38.52 & 0 \\
\hline & & & 1 & 11.67 & 0.06 \\
\hline & & & 2 & 1.27 & 0.3 \\
\hline & & 4 & 0 & 31.03 & 0 \\
\hline & & & 1 & 12.02 & 0.05 \\
\hline & & & 2 & 1.25 & 0.3 \\
\hline Consumption, income, & $c, \operatorname{shift}(04 q 1)$ & 1 & 0 & 135.63 & 0 \\
\hline stock mkt net wealth & & & 1 & 9.9 & 0.86 \\
\hline and non-stock mkt net & & & 2 & 5.27 & 0.53 \\
\hline wealth & & & 3 & 1.13 & 0.33 \\
\hline & & 2 & 0 & 71.03 & 0 \\
\hline & & & 1 & 18.77 & 0.21 \\
\hline & & & 2 & 9.4 & 0.15 \\
\hline & & & 3 & 2.63 & 0.12 \\
\hline & & 3 & 0 & 60.19 & 0 \\
\hline & & & 1 & 26.64 & 0.02 \\
\hline & & & 2 & 11.08 & 0.08 \\
\hline & & & 3 & 3.01 & 0.1 \\
\hline & & 4 & 0 & 65.71 & 0 \\
\hline & & & 1 & 29.13 & 0.01 \\
\hline & & & 2 & 11.49 & 0.07 \\
\hline & & & 3 & 2.63 & 0.12 \\
\hline Consumption, income, stock & $c, \operatorname{shift}(04 q 1)$ & 1 & 0 & 179.14 & 0 \\
\hline mkt net wealth, non-stock & & & 1 & 39.7 & 0.05 \\
\hline mkt net wealth and inflation & & & 2 & 30.57 & 0.01 \\
\hline & & & 3 & 8.61 & 0.19 \\
\hline & & & 4 & 1.35 & 0.28 \\
\hline & & 2 & 0 & 107.31 & 0 \\
\hline & & & 1 & 44.77 & 0.01 \\
\hline & & & 2 & 19.5 & 0.18 \\
\hline & & & 3 & 10.21 & 0.11 \\
\hline & & & 4 & 2.44 & 0.14 \\
\hline & & 3 & 0 & 104.49 & 0 \\
\hline & & & 1 & 44.91 & 0.01 \\
\hline & & & 2 & 20.19 & 0.15 \\
\hline & & & 3 & 9.66 & 0.13 \\
\hline & & & 4 & 3.16 & 0.09 \\
\hline & & 4 & 0 & 116 & 0 \\
\hline & & & 1 & 61.38 & 0 \\
\hline & & & 2 & 23.64 & 0.06 \\
\hline & & & 3 & 8.32 & 0.22 \\
\hline & & & 4 & 2.17 & 0.17 \\
\hline Consumption, income, stock & $c, \operatorname{shift}(04 q 1)$ & 1 & 0 & 135.24 & 0 \\
\hline $\begin{array}{l}\text { mkt asset and residual } \\
\text { net wealth }\end{array}$ & & & 1 & 10.11 & 0.84 \\
\hline
\end{tabular}

Table A1 (continued)

\begin{tabular}{|c|c|c|c|c|c|}
\hline Model & $\begin{array}{l}\text { Deterministic } \\
\text { term }\end{array}$ & $\begin{array}{l}\text { No. of } \\
\text { lags }\end{array}$ & $\mathrm{r}_{0}$ & $\begin{array}{l}\text { Test } \\
\text { value }\end{array}$ & $\begin{array}{l}\mathrm{p} \\
\text { value }\end{array}$ \\
\hline & & & 2 & 5.36 & 0.52 \\
\hline & & & 3 & 1.12 & 0.33 \\
\hline & & 2 & 0 & 71.64 & 0 \\
\hline & & & 1 & 19.09 & 0.2 \\
\hline & & & 2 & 9.62 & 0.14 \\
\hline & & & 3 & 2.64 & 0.12 \\
\hline & & 3 & 0 & 60.36 & 0 \\
\hline & & & 1 & 27.05 & 0.02 \\
\hline & & & 2 & 11.23 & 0.07 \\
\hline & & & 3 & 3.03 & 0.1 \\
\hline & & 4 & 0 & 66.03 & 0 \\
\hline & & & 1 & 29.13 & 0.01 \\
\hline & & & 2 & 11.65 & 0.06 \\
\hline & & & 3 & 2.62 & 0.12 \\
\hline \multirow{20}{*}{$\begin{array}{l}\text { Consumption, income, stock } \\
\text { mkt asset, residual net } \\
\text { wealth and inflation }\end{array}$} & $c, \operatorname{shift}(04 q 1)$ & 1 & 0 & 179.14 & 0 \\
\hline & & & 1 & 40.16 & 0.05 \\
\hline & & & 2 & 31.39 & 0 \\
\hline & & & 3 & 8.83 & 0.18 \\
\hline & & & 4 & 1.36 & 0.28 \\
\hline & & 2 & 0 & 108.17 & 0 \\
\hline & & & 1 & 45.41 & 0.01 \\
\hline & & & 2 & 19.99 & 0.16 \\
\hline & & & 3 & 10.38 & 0.1 \\
\hline & & & 4 & 2.48 & 0.14 \\
\hline & & 3 & 0 & 104.56 & 0 \\
\hline & & & 1 & 44.86 & 0.01 \\
\hline & & & 2 & 20.52 & 0.14 \\
\hline & & & 3 & 9.7 & 0.13 \\
\hline & & & 4 & 3.2 & 0.09 \\
\hline & & 4 & 0 & 116.46 & 0 \\
\hline & & & 1 & 61.14 & 0 \\
\hline & & & 2 & 23.22 & 0.07 \\
\hline & & & 3 & 8.37 & 0.21 \\
\hline & & & 4 & 2.16 & 0.17 \\
\hline \multirow{16}{*}{$\begin{array}{l}\text { Consumption, income, } \\
\text { house net wealth and } \\
\text { non-house net wealth }\end{array}$} & $c$, shift $(00 q 1)$ & 1 & 0 & 125.53 & 0 \\
\hline & & & 1 & 14.95 & 0.47 \\
\hline & & & 2 & 6.59 & 0.37 \\
\hline & & & 3 & 1.47 & 0.26 \\
\hline & & 2 & 0 & 63.98 & 0 \\
\hline & & & 1 & 15.80 & 0.4 \\
\hline & & & 2 & 9.21 & 0.16 \\
\hline & & & 3 & 4.23 & 0.05 \\
\hline & & 3 & 0 & 56.51 & 0 \\
\hline & & & 1 & 21.33 & 0.11 \\
\hline & & & 2 & 11.42 & 0.07 \\
\hline & & & 3 & 5.26 & 0.03 \\
\hline & & 4 & 0 & 58.99 & 0 \\
\hline & & & 1 & 23.86 & 0.05 \\
\hline & & & 2 & 12.29 & 0.05 \\
\hline & & & 3 & 5.16 & 0.03 \\
\hline \multirow{16}{*}{$\begin{array}{l}\text { Consumption, income, } \\
\text { house asset and residual } \\
\text { net wealth }\end{array}$} & $c, \operatorname{shift}(02 q 1)$ & 1 & 0 & 124.39 & 0 \\
\hline & & & 1 & 8.08 & 0.94 \\
\hline & & & 2 & 5.77 & 0.47 \\
\hline & & & 3 & 1.4 & 0.27 \\
\hline & & 2 & 0 & 63.33 & 0 \\
\hline & & & 1 & 14.43 & 0.51 \\
\hline & & & 2 & 6.74 & 0.36 \\
\hline & & & 3 & 1.87 & 0.2 \\
\hline & & 3 & 0 & 55.72 & 0 \\
\hline & & & 1 & 21.53 & 0.11 \\
\hline & & & 2 & 9.47 & 0.14 \\
\hline & & & 3 & 3.08 & 0.09 \\
\hline & & 4 & 0 & 54.48 & 0 \\
\hline & & & 1 & 19.43 & 0.18 \\
\hline & & & 2 & 9.96 & 0.12 \\
\hline & & & 3 & 3.69 & 0.06 \\
\hline \multirow{10}{*}{$\begin{array}{l}\text { Consumption, income, } \\
\text { house asset, residual } \\
\text { net wealth and inflation }\end{array}$} & $c, \operatorname{shift}(02 q 1)$ & 1 & 0 & 189.56 & 0 \\
\hline & & & 1 & 25.82 & 0.6 \\
\hline & & & 2 & 17.67 & 0.27 \\
\hline & & & 3 & 6.86 & 0.34 \\
\hline & & & 4 & 1.49 & 0.26 \\
\hline & & 2 & 0 & 107.13 & 0 \\
\hline & & & 1 & 34.9 & 0.15 \\
\hline & & & 2 & 14.44 & 0.51 \\
\hline & & & 3 & 7.84 & 0.23 \\
\hline & & & 4 & 1.32 & 0.29 \\
\hline
\end{tabular}


Table A1 (continued)

\begin{tabular}{|c|c|c|c|c|c|}
\hline Model & $\begin{array}{l}\text { Deterministic } \\
\text { term }\end{array}$ & $\begin{array}{l}\text { No. of } \\
\text { lags }\end{array}$ & $\mathrm{r}_{0}$ & $\begin{array}{l}\text { Test } \\
\text { value }\end{array}$ & $\begin{array}{l}\mathrm{p} \\
\text { value }\end{array}$ \\
\hline & & 3 & 0 & 100.05 & 0 \\
\hline & & & 1 & 38.74 & 0.07 \\
\hline & & & 2 & 16.8 & 0.33 \\
\hline & & & 3 & 7.85 & 0.25 \\
\hline & & & 4 & 2.14 & 0.17 \\
\hline & & 4 & 0 & 107.46 & 0 \\
\hline & & & 1 & 54.74 & 0 \\
\hline & & & 2 & 17.15 & 0.31 \\
\hline & & & 3 & 7.99 & 0.24 \\
\hline & & & 4 & 2.92 & 0.1 \\
\hline \multirow{16}{*}{$\begin{array}{l}\text { Consumption, income, } \\
\text { liquid net wealth and } \\
\text { illiquid net wealth }\end{array}$} & $c, \operatorname{shift}(99 q 1)$ & 1 & 0 & 147.83 & 0 \\
\hline & & & 1 & 24.16 & 0.05 \\
\hline & & & 2 & 8.65 & 0.19 \\
\hline & & & 3 & 0.8 & 0.42 \\
\hline & & 2 & 0 & 81.46 & 0 \\
\hline & & & 1 & 25.25 & 0.04 \\
\hline & & & 2 & 10.14 & 0.11 \\
\hline & & & 3 & 1.62 & 0.24 \\
\hline & & 3 & 0 & 75.14 & 0 \\
\hline & & & 1 & 30.22 & 0.01 \\
\hline & & & 2 & 10.06 & 0.12 \\
\hline & & & 3 & 1.35 & 0.28 \\
\hline & & 4 & 0 & 72.83 & 0 \\
\hline & & & 1 & 37.41 & 0 \\
\hline & & & 2 & 11.06 & 0.08 \\
\hline & & & 3 & 0.97 & 0.37 \\
\hline \multirow{16}{*}{$\begin{array}{l}\text { Consumption, income, } \\
\text { liquid asset and residual } \\
\text { net wealth }\end{array}$} & $c, \operatorname{shift}(99 q 1)$ & 1 & 0 & 147.88 & 0 \\
\hline & & & 1 & 25.51 & 0.03 \\
\hline & & & 2 & 8.9 & 0.18 \\
\hline & & & 3 & 0.77 & 0.43 \\
\hline & & 2 & 0 & 82.25 & 0 \\
\hline & & & 1 & 25.72 & 0.03 \\
\hline & & & 2 & 10.49 & 0.1 \\
\hline & & & 3 & 1.56 & 0.25 \\
\hline & & 3 & 0 & 75.96 & 0 \\
\hline & & & 1 & 30.17 & 0.01 \\
\hline & & & 2 & 10.27 & 0.11 \\
\hline & & & 3 & 1.26 & 0.3 \\
\hline & & 4 & 0 & 72.89 & 0 \\
\hline & & & 1 & 37.38 & 0 \\
\hline & & & 2 & 11.22 & 0.07 \\
\hline & & & 3 & 0.94 & 0.38 \\
\hline
\end{tabular}

Notes: All data are in log and real per capita except for inflation. Deterministic terms: constant and level shift dummy. Shift(98q1), for example, is one from 1998q1 to zero before.

\section{References}

Ando, A., Modigliani, F., 1963. The life cycle hypothesis of saving: aggregate implications and tests. The American Economic Review 53, 55-84.

Apergis, N., Miller, S.M., 2004. Consumption asymmetry and the stock market: empirical evidence. Working Paper No. 2004-43. Department of Economics, University of Connecticut.

Asteriou, D., Hall, S.G., 2007. Applied Econometrics: A Modern Approach using Eviews and Microfit Palgrave MacMillan, New York.

Benjamin, J.D., Chinloy, P., Jud, G.D., 2004. Real estate versus financial wealth in consumption. Journal of Real Estate Finance and Economics 29, 341-354.
Carroll, C., Otsuka, M., Slacalek, J., 2006. How large is the housing wealth effect? A new approach. Working Paper No. 12476. National Bureau of Economic Research.

Davis, M.A., Palumbo, M.G., 2001. A primer on the economics and time series econometrics of wealth effects. Finance and Economics Discussion Paper Series No. 2001-09. Board of Governors of the Federal Reserve System, Washington, DC.

Deaton, A., 1977. Involuntary saving through unanticipated inflation. The American Economic Review 67, 899-910.

Donihue, M.R., Avramenko, A., 2006. Decomposing consumer wealth effects: evidence on the role of real estate assets following the wealth cycle of 1990-2002. Working Paper No. 06/15. Federal Reserve Bank of Boston.

Duca, J.V., 2006. Making sense of the U.S. housing slowdown. Economic Letter 1 (11), 1-8 (Federal Reserve Bank of Dallas, November)

Duca, J.V., Kumar, A., 2011. Financial literacy and mortgage equity withdrawals. Working Paper No. 1110. Federal Reserve Bank of Dallas.

Enders, W., 1995. Applied Econometric Time Series. John Wiley, New York.

Forsyth, J., 1975. Saving, inflation and recession. Morgan Grenfell Economic Review 1-8 (Sept. 9).

Friedman, M., 1957. A Theory of the Consumption Function. Princeton University Press, Princeton.

Fuentes, M., Hatzius, J., 2006. Mortgage Equity Withdrawal: The Key Issue for 2006. US Economics Analyst, Goldman Sachs. Issue 05/46.

Greenspan, A., Kennedy, J., 2005. Estimates of home mortgage originations, repayments, and debt on one-to-four-family residences. Finance and Economics Discussion Series No. 2005-41. Board of Governors of the Federal Reserve System, U.S.

Greenspan, A., Kennedy, J., 2008. Sources and uses of equity extracted from homes. Oxford Review of Economic Policy 24, 120-144.

Gylfason, T., 1981. Interest rates, inflation and the aggregate consumption function. The Review of Economics and Statistics 63, 233-245.

Heien, D.M., 1972. Demographic effects and the multiperiod consumption function. Journal of Political Economy 80, 125-138.

Hendry, D.F., von Ungern-Stenberg, T., 1981. Liquidity and inflation effects on consumers' expenditure. In: Deaton, A.S. (Ed.), Essays in the Theory and Measurement of Consumers Behaviour. Cambridge University Press, pp. 237-260.

Howard, D.H., 1978. Personal saving behavior and the rate of inflation. The Review of Economic and Statistics 60, 547-554.

Katona, G., 1975. Psychological Economics. Elsevier, New York.

Leonard, J.A., 2010. The Impact of the Housing Market Boom and Bust on Consumption Spending. Business Economics 45, 83-93.

Ludvigson, S., Steindel, C., 1999. How important is the stock market effect on consumption? Economic Policy Review 5, 29-51.

MacDonald, G., Mullineux, A., Sensarma, R., 2011. Asymmetric effects of interest rate changes: the role of the consumption-wealth channel. Applied Economics 43, 1991-2001.

Mehra, Y.P., 2001. The wealth effect in empirical life-cycle aggregate consumption equations, Federal Reserve Bank of Richmond. Economic Quarterly 87, 45-78.

Mishkin, F.S., 1976. Illiquidity, consumer durable expenditure, and monetary policy. The American Economic Review 66, 642-654.

Mishkin, F.S., 1992. Is the Fisher effect for real? A reexamination of the relationship between inflation and interest rates. Journal of Monetary Economics 30, 195-215.

Prakken, J., 2006. Fear not MEW. Macro Focus 1 (2).

Rudd, J., Whelan, K., 2002. A note on the cointegration of consumption, income, and wealth. Working Paper No. 2002-53. Federal Reserve Board.

Rudd, J., Whelan, K., 2006. Empirical proxies for the consumption-wealth ratio. Review of Economic Dynamics 9, 34-51.

Springer, W.L., 1975. Did the 1968 surcharge really work? The American Economic Review 65, 644-659.

Springer, W.L., 1977. Consumer spending and the rate of inflation. The Review of Economics and Statistics 59, 299-306.

Stock, J.H., Watson, M.W., 1993. A simple estimator of cointegrating vectors in higher order integrated systems. Econometrica $61,783-820$.

Taylor, L.D., 1971. Saving out of different types of income. Brooking Papers on Economic Activity 2, 383-415.

Walsh, C.E., 2003. Monetary Theory and Policy. The MIT Press, Cambridge, Massachusetts.

Weber, W.E., 1975. Interest rates, inflation, and consumer expenditures. The American Economic Review 65, 843-857.

Wilcox, J.A., 1990. Nominal interest rate effects on real consumption expenditure. Business Economics 25, 31-38. 